DANMARKS GEOLOGISKE UNDERSOGELSE

II. Rakke. Nr. 110

Geological Survey of Denmark. II. Series. No. 110

\title{
Deglaciation landscapes formed during the wasting of the late Middle Weichselian ice sheet in Denmark
}

\author{
BY \\ Ib Marcussen
}

DANSK SAMMENDRAG:

Deglaciations landskaber dannet under smeltningen af isskjoldet $\mathrm{i}$ sen mellem weichsel i Danmark

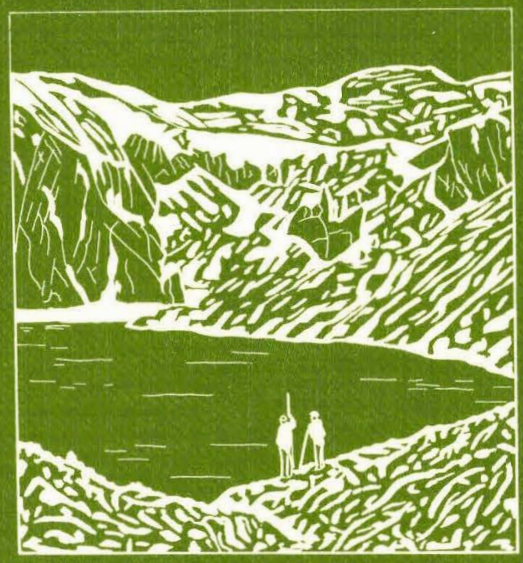

I kommission hos C. A. Reitzels Forlag. København 1977 
Danmarks Geologiske Undersøgelse. II. Række Nr. 110

Geological Survey of Denmark. II. Series. No. 110

\section{Deglaciation landscapes formed during the wasting of the late Middle Weichselian ice sheet in Denmark}

By

Ib Marcussen

Dansk sammendrag:

Deglaciations landskaber dannet under smeltningen af isskjoldet i sen mellem weichsel i Danmark

I kommission hos C. A. Reitzels Forlag

København 1977 
D.G.U. II. rk. nr. 110

er sat med Linotype Times

og trykt i offset i 1000 eksemplarer

hos Andelsbogtrykkeriet i Odense.

Bogen er trykt på Thai-Cote, $115 \mathrm{~g}$

fra a/s De forenede Papirfabrikker.

ISBN 87-421-0705-9.

Date of publication: 1977-03-31.

Lakelet on Malaspina Glacier, Alaska Vignet after drawing in

Russel 1897, fig. 9. 


\section{Contents}

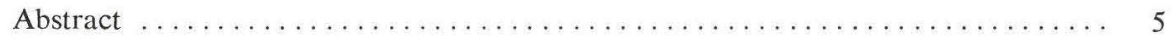

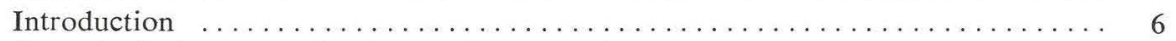

Glaciological concepts in the previous Danish literature ............... 9

Considerations on general glaciological, climatological and sedimentological con-

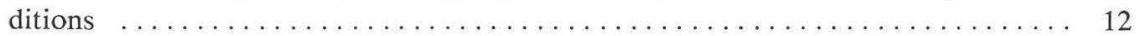

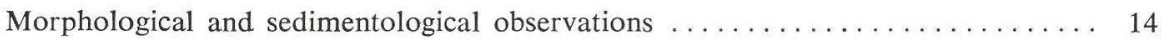

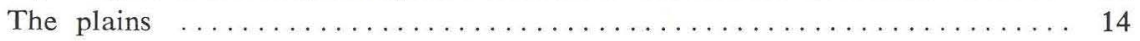

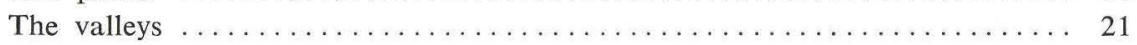

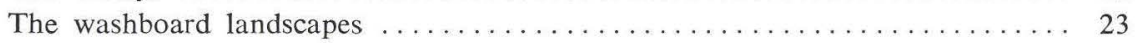

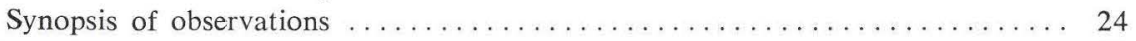

Discussion . . . . . . . . . . . . . . . . . . . . . . . . . . . . . . 29

Discussion of the current concepts in the literature $\ldots \ldots \ldots \ldots \ldots \ldots \ldots .30$

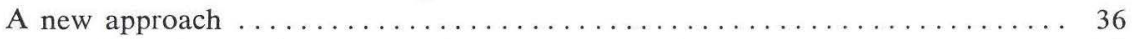

Area-wasting of a continental cold ice sheet; a model ................ 43

Glaciological and climatological implications for the last glaciation in Denmark . . 51

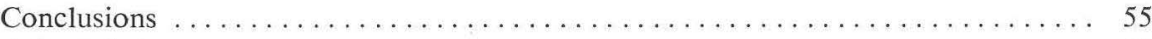

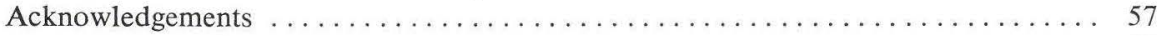

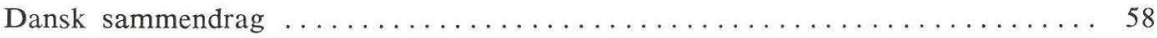

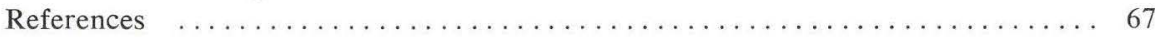




\section{Abstract}

On the basis of paleoclimatological observations the thermal regime of the Weichselian ice in the Danish area is considered in this paper to have been subpolar. The glaciological and glacial-geological consequences of this concept are discussed. Contrary to current opinion it is argued that the Weichselian ice in the Danish area formed an ice sheet containing englacial debris. Observations of plains arranged in a step-like manner, of terraces in the "tunnel"valleys connected with the plains and hanging tributary valleys, and of washboard landscapes gradually passing into plains are presented. These features are interpreted as supraglacial sandurs (down-wasting plains), elongated kettles (down-wasting valleys) and Thule-Baffin moraines formed during area-wasting of the ice sheet. The ablation deposits are considered to be partially controlled by structures in the ice sheet. The topography of the substratum of the ice sheet prior to the wasting phase may have influenced the distribution and morphology of the ablation deposits. The ablation deposits appear to form a carpet over euglacial deposits like lodgement till in considerable areas of the country. The wide occurrence of separate plains and the step-like arrangement may be the result of area-wasting influenced by climatic fluctuations. 


\section{Introduction}

The stratigraphy of the Weichselian deposits in the Danish area has been discussed eagerly in the last 100 years. The previous studies have been concerned essentially with the advance of the ice and especially with the route the ice followed to the Danish area and within the area. A very complicated glacial-stratigraphy has thus been established for the Weichselian in southern Scandinavia and northwest Germany.

A glaciation can, however, be regarded as consisting of two series of processes each dominated by different agents. In the euglacial series of processes the physical properties of the glaciers will mainly characterize the deposits, whereas in the deglaciation series of processes, water will be the active agent. In this latter series the processes are also strongly influenced by the remaining, and melting, ice. The two series of processes can overlap to some degree, but it is nevertheless most important to distinguish between the respective types of deposits. The euglacial deposits can be more or less well-developed and are in many cases difficult to distinguish, while the sedimentological and morphogenetic capabilities of water make ablation deposits formed by the deglaciation processes easier to become aware of.

During the retreat of the ice a displacement of the line separating the active part of the ice sheet from the stagnant parts took place. If the movement of this line was interrupted within short distances this is frequently referred to as frontal wasting of the ice. Most Danish authors maintain this idea, which for example appears in maps by V. Milthers (1948) and S. Hansen (1965). However, in cases where long distances exist between the halts it is convenient to speak of area wasting (S. A. Andersen 1931, p. 164). In both cases, masses of ice are more or less prevented from taking part in the general flow pattern and are referred to as stagnant ice. Ussing (1907, p. 185) is of the opinion that zones of such ice with a thick cover of debris terminated the living glacier and formed the irregular moraine landscape.

As a contribution to the discussion of the Weichselian ice recession in Denmark it is the intention of this paper to discuss deposits which may be the results of the deglaciation processes by mean of some characteristic 
examples. The features in question can however be found in most parts of the country and may thus be described as being of general occurrence. The main emphasis has been laid on the morphology of the deposits, but the sedimentological composition and the setting have also been examined.

The discussion of the genesis of the deposits considered here will as far as possible be based on glaciological and glacial-geological observations of recent glaciers and ice sheets. In this respect this study follows the lines marked out by Ussing (1899, 1900, 1903, 1904). But since knowledge of glacial-geology has increased considerably since then, it will be in the spirit of Ussing's views to adjust his hypotheses to the recent level of discussion. In a comment on older hypotheses Ussing (1903 p. 100, translatet from Danish) expressed it in this way: "Many examples can be quoted where suppositions which originally are stated as such gradually by virtue of the hypotheses have been considered facts although investigations have in no respect confirmed them". 


\section{Glaciological concepts in the previous Danish literature}

Climatological conditions like precipitation and temperature are of essential importance for the regime and behaviour of glaciers.

The amount of precipitation during the last glaciation has not been discussed directly in the Danish literature. But the lively glacial activity which is generally assumed to have operated, implies temperate conditions, probably and a considerable accumulation (Sugden and John 1976). Paleoclimatological observations in Holland (Hammen et al 1971) do not support that assumption.

The temperature conditions are important for physical properties such as flow and permeability of glacier ice. Ussing (1907 p. 206) estimated the annual mean temperature during the glaciation to have been considerably over the freezing point. This view has guided the studies of the behaviour of the Weichselian ice in the Danish area.

It is generally accepted in the literature that the Weichselian glaciers in the Danish area were of the temperate type that moved on top of the landscape we see to-day on a subglacial water film. End moraines of variable size were formed at the front of the ice masses. Several glaciations are considered to have taken place during the Weichselian. The glaciers moved from two main directions and were of two different morphological types. From the more highlysituated accumulation areas north and northeast of Denmark a continuous ice sheet is considered to have moved down and covered the northern parts of the country. Later a huge glacier is assumed to have separated from the Scandinavian ice sheet and to have moved through the Baltic from north to south. This ice tongue changed direction at about the southern part of Sweden and flowed to the west and northwest over the Danish area. In the literature it is mentioned as the Baltic ice. The morphological type of this body of ice is assumed to have changed as time went on. At first it was a gigantic piedmont glacier with a heavily lobated front. Later on the ice developed long narrow tongueshaped glaciers like those in mountainous regions.

These hypotheses are based on some thoughts put forward by Torell (1872). The ideas were further developed by many authors among whom $\mathrm{V}$. Milthers is especially outstanding. The basis for these studies was particularly the differences in the lithological composition of the stone material 
in the tills. The difference from till to till or from one locality to another was considered to reflect in some way the routes of the glaciers which deposited the tills (V. Milthers 1909, 1932, K. Milthers 1942). However, studies of the morphology of the landscapes have also been used, but always on the premisses (a very active, temperate ice mass) mentioned at the beginning of the chapter (V. Milthers 1900, Harder 1908, Smed 1962, Krüger 1969).

V. Milthers (1900) interpreted a system of hills in northwest Sjælland as the terminal moraines of three narrow glacier tongues. The flat areas in front of the moraines were interpreted as sandur plains and the low areas within the moraines to be the result of subglacial erosion. Milthers did not refer to any recent glacier or glacier type, but it seems most probable that valley glaciers in the Alps were the model. This model has been the basis of the concepts of the Weichselian glacier ice in the Danish area until recently. However, already at the beginning of the century it was obvious that many observations did not fit into this glacier model, but this problem was ascribed to the special conditions supposed to have existed in the Danish area (Harder 1908, p. 4).

In the Danish literature it is assumed that the meltwater could move freely through the ice and that the drainage was consequently subglacial. This concept indicates a glacier with a temperature at the pressure melting point all the way through a feature peculiar to temperate glaciers. As glaciers of this type seem to move on a layer of water, very little material will be incorporated in the ice, and the glacier will therefore be white and debrisfree - a feature which can be observed in recent temperate glaciers. The Weichselian glaciers should therefore also have been debris-free. Some deposits are nevertheless interpreted by many authors as deposited in hollows in the glacier surface. The material must therefore have been lying on the glacier surface, which is in conflict with the view that the glaciers were temperate and therefore debris-free.

The outlined set of concepts concerning the Weichselian ice, its activity and the glacial stratigraphy is based on the assumption that till is exclusively deposited from the undersurface of the glacier. Consequently, the genesis and development of a certain morphological feature is considered differently depending on whether the top-layer consists of till or not. However, till derived from the supraglacial environment has also been demonstrated in the Danish Weichselian glacigene deposits (Jessen 1918, 1936, Mertz 1937, 1955, 1959, Marcussen 1973, 1975). An interpretation of the landscapes and the deposits under consideration of occurrences of lodgement till as well as flow till has never been attempted on a larger scale in the Danish area. 
The model for the disappearance of the ice as it can be deduced from the literature involves a frontal wasting, followed by a rejuvenation of the glacier and establishment of a new end moraine at a more proximal position. The deglaciation should therefore be characterized by a serie of successive end moraines with corresponding sandur plains. In spite of descriptions of numerous end moraines in the eastern part of the country, only a few sandur plains of small and insignificant size have been demonstrated.

Since several features do not fit with the outlined deglaciation model, it will be attempted to establish another model which hopefully can explain some observations, but which on the other hand leaves other problems open. 


\section{Considerations on general glaciological, climatological and sedimentological conditions}

The Scandinavian mountains acted as the accumulation area for the Weichselian ice sheet. The terminus of the ice sheet seems to have moved during the period (J. Lundqvist 1974). It is still under discussion whether the ice sheet reached the Danish area more than once during the Weichselian. Some observations (Konradi and Knudsen 1974) indicate that the northern regions of the country were only glaciated in the late part of the Middle Weichselian. In other parts of the country there are no observations indicating the stratigraphical position of the glaciation, but a conformity with the northern part may be reasonably assumed.

It is supposed that the relief in the Danish area was low prior to the last glaciation in the same way as it is to-day. Observations on ice sheets moving on a flat, non-mountainous substratum indicate a simple pattern of distribution and an unbroken front. Parts of the ice sheet in Greenland (Fristrup 1963) and the Barnes ice cap (Sagar 1966) indicate this. However, differences in physical properties (inter alia variations in the amount of incorporated debris) may cause ice streams in the ice sheet. It should consequently be expected that the Weichselian ice spread out as an ice sheet over the Danish area from a northern and northeastern direction with a rather uncomplicated flow pattern. This theoretical model is supported by some important observations. The striation of the basement in southern Sweden shows a consistent pattern towards the southwest (G. Lundqvist 1954). Because of a drastic change from hard metamorphic rocks in the substratum to soft sediments further south the striation does not continue. But the simple and ubiquitous pattern of morphological structures in the Danish area form a natural continuation of the mentioned striation pattern (Marcussen 1974). Fabric analyses in lodgement tills in Denmark (Marcussen 1975) also strengthen this concept.

The climatological conditions in the late part of the Middle Weichselian in the Danish area can be estimated from observations at locations outside the glaciated areas (Coope et al. 1971, van der Hammen et al. 1971, McIntyre and Ruddiman 1972, Kellog 1976). The data available makes it most probable that the climate in southern Scandinavia was subpolar or maybe even high arctic. It is not only the regime conditions and the altitude 
of the firn line which are related to the climate, but also some features of great importance for the glacial-geological environment. Thus, the temperature conditions of the ice sheet affect the movement of the ice over the substratum and the drainage of the meltwater in an essential way. Cold glaciers (polar and subpolar) have only a restricted effect on their beds, because the movement takes predominantly place as internal flow. Polar glaciers are frozen to the substratum, on which their influence is therefore extremely little, if it occurs at all. In subpolar glaciers the temperature is also below the pressure-melting point, but it can be just below this point in the bottom zone. Changes in the stress can therefore result in melting and refreezing of parts of the ice. Through such processes material from the substratum can be incorporated in the basal parts of the ice (Boulton 1970). Material enclosed in the ice will move with the glacier and will first be released in the frontal zone (Goldthwait 1951, Bishop 1957, Weertman 1961, Boulton 1967) or on the surface by thawing (Tarr 1909, Gripp and Todtmann 1926, Gripp 1929, Sharp 1947, Ward 1957, Boulton 1968, 1971, 1972a).

Since the temperature of the ice in cold glaciers is below the pressuremelting point, the ice will be impermeable to the meltwater. The drainage of the water from the surface ablation will consequently be supraglacial. Where englacial material is released on the surface an extraordinary sedimentological environment will develop. The supraglacial landscape will be very like a karst topography and has been described as thermokarst (Clayton 1964).

The total wasting of an ice sheet of a considerable thickness (probably several hundred metres in this case) has never been observed. As pointed out by Sharp (1909 p. 313) "continental glaciation afford better opportunity for preserving accumulations of superglacial origin" than valley glaciers. Consequently, the deglaciation deposits resulting from the wasting of a debris-loaded ice sheet should be expected to have a larger extent, be more shapely and more widely distributed than those described from recent valley glaciers. The deposits can be expected to consist of subhorizontally layered sediments and to appear in landforms with a roughly flat, horizontal surface like that of sandur plains. Since the deposition occurred on or at least in close contact with the thawing ice the internal structures as well as the exterior forms of the deposits can be expected to show deformations.

The surface of the ice sheet was probably almost horizontal (Wolf 1928) and a climatic amelioration would therefore effect large areas at the same time (v. Bülow 1928, Andersen 1931, Richter 1937). The increased ablation would most probably result in an area-down-wasting of broad zones of the ice sheet. 


\section{Morphological and sedimentological observations}

Glacial deposits from the Weichselian form the essential part of the Danish landscape. The sediments comprise till and meltwater deposits of clay, sand and gravel. With respect to genesis two types of till have so far been described: lodgement till and flow till (e.g. Marcussen 1975).

The morphology of the deposits has been investigated by many authors, generally with the intention of finding indications of glacier movement or to confirm such a movement established by other indications (e.g. by indicator boulders). The present paper has a mainly morphogenetic purpose and does not directly address the question of glacier movements. However, the oriented structures in the depicted landscapes, which may have been inherited from the moving glacier, will be incidentally mentioned.

The morphological studies have been carried out on maps of scale 1:20000. The sedimentological observations are based on the geological maps from the Geological Survey of Denmark, on the Well Records Department of the Geological Survey, and on field studies.

The largest and most conspicuous morphological features in the Danish landscapes are the plains and the "tunnel" valleys. Both of them are of widespread occurrence; five examples which are considered to be representative will be described. A third common feature to be considered is the elongated hills which form a morphology reminiscent of a washboard.

\section{The plains}

Two main types of plains may be distinguished. They are, however, connected by all possible transitions. In this describtion only some representative examples will be considered. The one main type of plains comprises flat, continuous areas with a gently rolling topography which does not form any consequent pattern. Such plains are tentatively named ortho-plains.

The other main type of plains is more difficult to become aware of, but it is on the other hand just as distinct in the landscape as the first type. These plains are defined by the flat tops which frequently have the same altitude over a considerable area. The flat tops obviously represent a disintegrated plain, which is tentatively named a para-plain. 


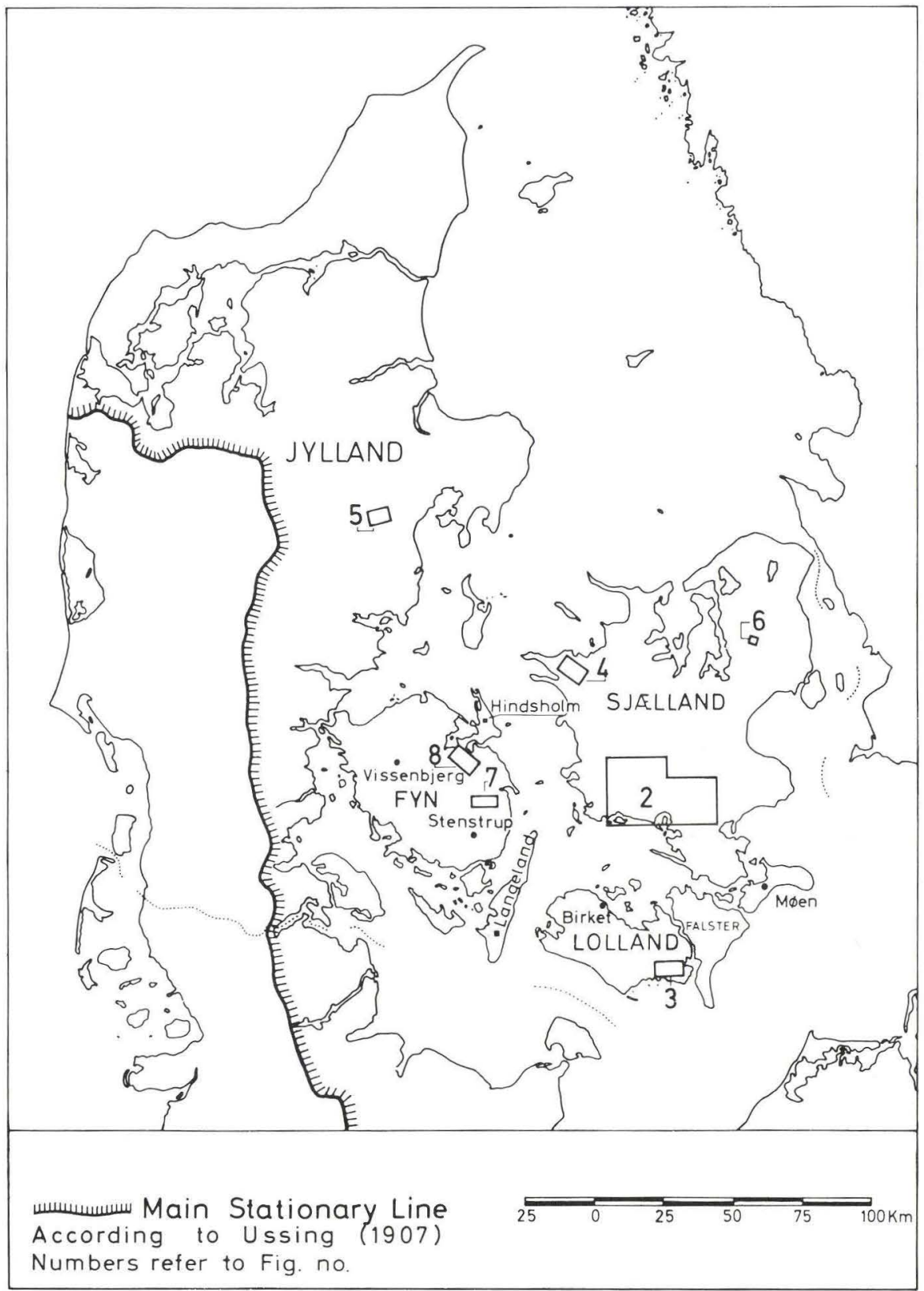

Fig. 1. Key-map indicating the described localities. 
The ortho-plains - In some area a plain can be followed over several square-kilometres or even through a whole province as for example in Sjælland. The plains may be arranged like steps in a very wide, stepped pyramide. The transitions between the individual plains (the steps) may in many places show an icecontact character. However, the transition can also be smooth and insensible. The last-mentioned feature is most common between the lowest lying plains, whereas the highest plains are always delimited by steep slopes.

Fig. 2 shows a part of southern Sjælland (see key-map fig. 1). In this area several plains have been observed but only the four lowest lying ones are depicted. The plain designated $45-55 \mathrm{~m}$ a.s.1. comprises two plains (47 ( \pm 2-3) m a.s.l. and $52( \pm 2-3) \mathrm{m}$ a.s.l.) of which the lower one is subordinate with respect to area. The morphological forms in the depicted landscape show a preferred orientation from northwest to southeast.

In the area shown in Fig. 2, and also in a more regional sense, some plains seem more important than others. The plain at $52 \mathrm{~m}$ a.s.l. is of special interest. It is at the bottom middle of the map composed of some elongated hills, which have been described as crevasse fillings (Andersen 1931). These hills can be traced distinctly in a northwesterly direction for about 20 kilometres where they continue in a large plain (in the upper left part of the map). In the elongated hills there are many pits showing gravelly and sandy meltwater sediments. The large plain is composed of a mixture of clayey, layered, loose till and meltwater sediments. Observations and the

Fig. 2. Map indicating down-wasting plains in southern Sjælland. The interpretation is based on maps of scale 1:20000 with 2.5 metre contour intervals. The constant altitude of several hills top has been given weight for establishing the respective plains. In each plain are included areas lying lower than the plain but higher than the immediately subjacent plain. Such areas are considered to have been deposited together with the plain, but they rested on ice. To enable the reader to evaluate the variations the altitude of the points of measurement (on the 1:20000 map, Geodetic Institute, Copenhagen) are plotted on the map. The two plains at about $55 \mathrm{~m}$ a.s.l. and $45 \mathrm{~m}$ a.s.l. respectively are not specified but are depicted with the same signature. The lowermost of these plains comprises rather small and scattered areas in the depicted landscape. Lithologically the landscape is very complex. Sorted sediments are the main constituent and in all the profiles investigated the till present shows features characteristic of flow till. Note the braided river system cut down into the plain at 21-26 $\mathrm{m}$ a.s.1. in the centre of the figure. The streams probably drained the melting ice situated in the depression which today contain the lake. The whole valley has been interpreted as a "tunnel"valley (Andersen 1924, K. Hansen 1944, V. Milthers 1948), but is in this paper considered to be a down-wasting valley, which acquired its present appearance during the wasting of he Weichselian ice. For further discussion, see text. 


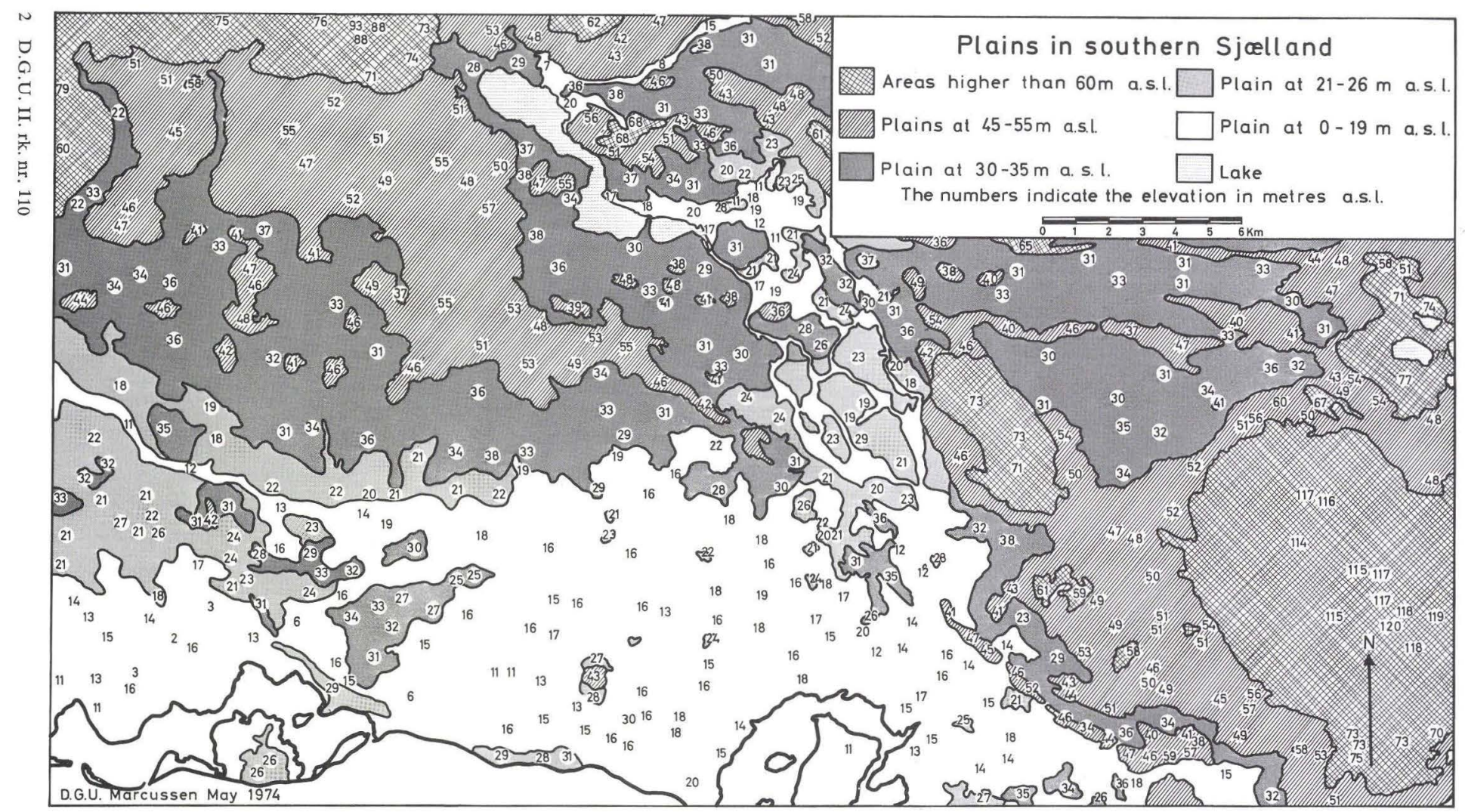




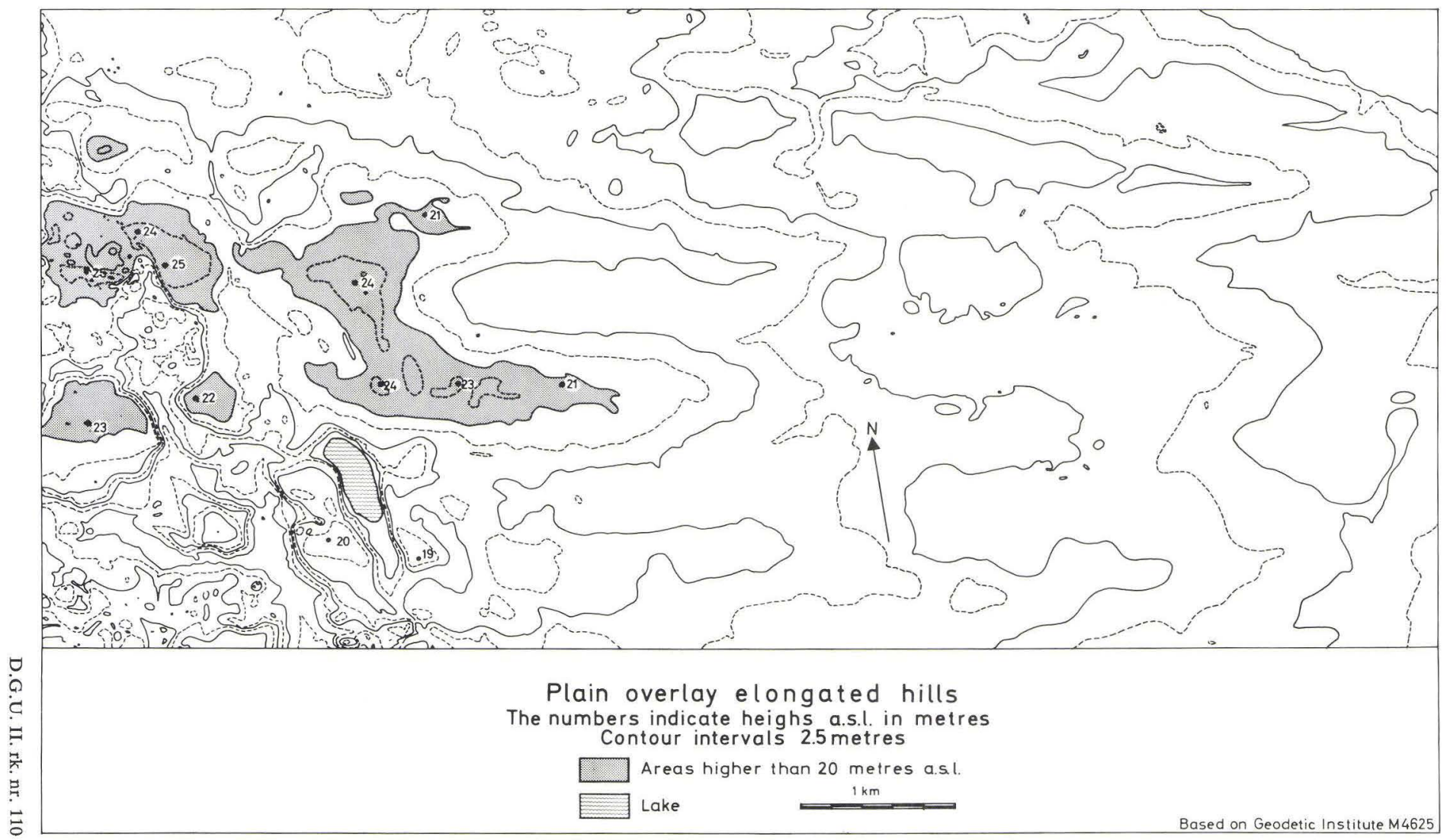


remnants after brickworks indicate that fine-grained fractions dominate the sediments making up the plain.

In the main part of Sjælland it is possible to distinguish several similar plains. Some of them have a local occurrence, but with some caution it is possible to identify most of the plains in the whole island.

In other parts of the country elevated plains are very common too. The eastern part of Jylland has been described by many authors as a plateau landscape with plains between the deep "tunnel"valleys (Nordmann 1958, Ødum 1969). In the island of Fyn it is a little more difficult to perceive the plains. However, the constant altitude of the summits of the hills in restricted areas indicates the existence of disintegrated plains, described as para-plains in this paper. At two locations in Fyn, Vissenbjerg (V. Milthers 1940) and Stenstrup (Madsen 1903, Nordmann 1922), plains of considerable size have been described.

In fig. 3 is depicted a landscape from the eastern part of Lolland. In the eastern part of the map distinct elongated low hills are predominant. The orientation of the hills are form northwest to southeast. In the western, and especially in the southwestern part, the orientation is weak or absent and the hills are higher and have flat tops. These hills are parts of a widespread plain at 20-25 m a.s.l., which can be traced all over the islands of Lolland and Falster. The Birket area (Marcussen 1973) is a part of this plain. A mapping of the superficial sediments in the area (fig. 3) indicates that the low-lying and eastern part of the hills consists mainly of compact clayey till. The high flat parts in the west are composed of sand, gravel and flow till. The presence of many gravel pits in the plain confirms this observation. The morphological unit of the plain appear to overlie and hide the elongated hills.

The para-plains - This type of plain is broken up into isolated hills whose tops have the same altitude. The form of the hills is very variable in shape as well as slope. The hills typically have an irregular form with a tendency to be circular or elliptical in outline, frequently with pseudopodium-like spurs. The hills are generally limited or partly limited by steep slopes. In

Fig. 3. Contour map of the southeastern part of Lolland. The low elongated hills on the east side of the figure consist of a dense, hard, clayey till interpreted as a lodgement till. Gravel pits in the more highly-situated deposits indicate that the plain consists of sorted sediments and flow till. The flat areas higher than 20 metres a.s.l. are interpreted as the remains of a down-wasting plain. The ablation deposits superimpose lodgement till and basal meltout till. The area is also shown in fig. 10 and on the map fig. 14. Copyright Geodetic Institute. 


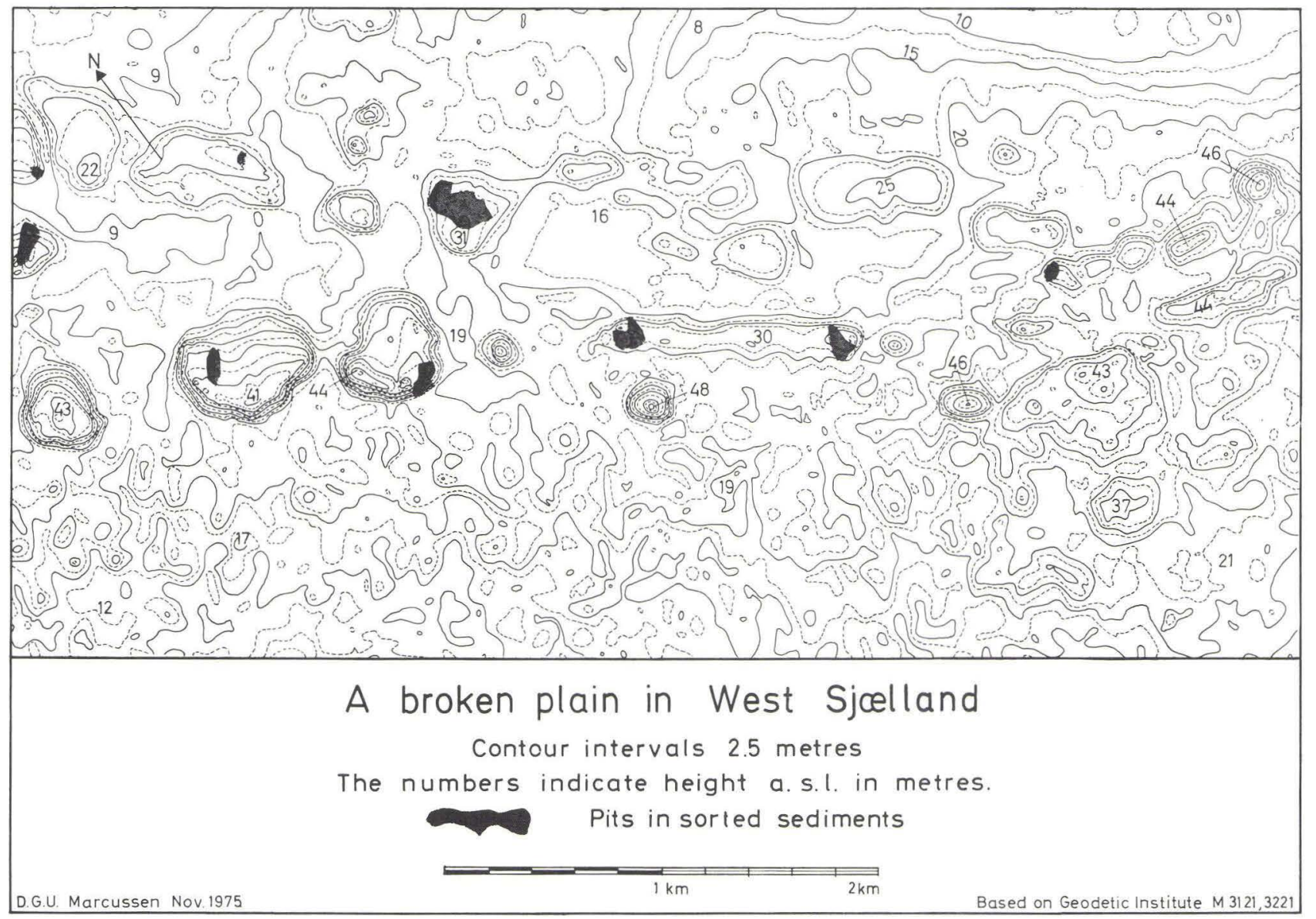


the literature, hills with this appearance are usually described as kames since they consist of meltwater sediments and flow till. This type of hill is known from many regions of the country. In fig. 4 an example from the western part of Sjælland is depicted. The top-altitude of the highest and most outstanding hills is on average $45 \mathrm{~m}$ a.s.l. with a couple of metres in deviation. The existence of gravel pits and a brickworks in the hills indicate the presence of sorted sediments. The layering of the sediments is horizontal (S. A. Andersen 1964).

\section{The valleys}

Some of the valleys in the plains are indisputably formed by stream erosion in Post- or Late Glacial times. These valleys are usually of a small size and form a dendritic drainage pattern in the landscape.

Another type of valley is broad and shallow with a flat bottom consisting of waterlaid sediments (e.g. the broad valley showing the braided river system in the center of fig. 2). These valleys may be termed river valleys.

A third type of valley in the plains has in the literature been designated "tunnel" valleys. These valleys are typically conspicuously large in relation to the stream they usually hold and it seems unrealistic to consider this stream responsible for the erosion of the valley. Very often the edge between the valley and the surrounding plain is distinct and forms a shoulder (fig. 5 and 6). At such places the side of the valley is steep. At other places the edges are smoother, but are anyhow practically always well marked. The valley can suddenly close in a circusform without becoming narrower (fig. 5 and 7). The valleys have terraces which in many cases can be connected to the bottom level of a hanging tributary valley (fig. 7). Generally one or more of the terraces can be traced out of the valleys, where they continue as plains (fig. 2 and 7).

The longitudinal bottom profile of the "tunnel" valleys is typically very uneven. The deepest basins are to-day lakes or bogs. Between the deep parts are thresholds which most frequently consist of sorted sand. In cases where the threshold is not a flat terrace the surface is very uneven with

Fig. 4. The tops of the rounded hills which consist mainly of sorted sediments (the existing pits are inserted) form a plain. The hills were created by a filling-in of hollows on the ice surface. The plain has only survived because parts of the deposits rested on the substratum below the ice and not entirely on the ice itself. The fuzzy topography in the upper part of the figure indicates the great unevenness of the wasting of the ice. Copyright Geodetic Institute. 


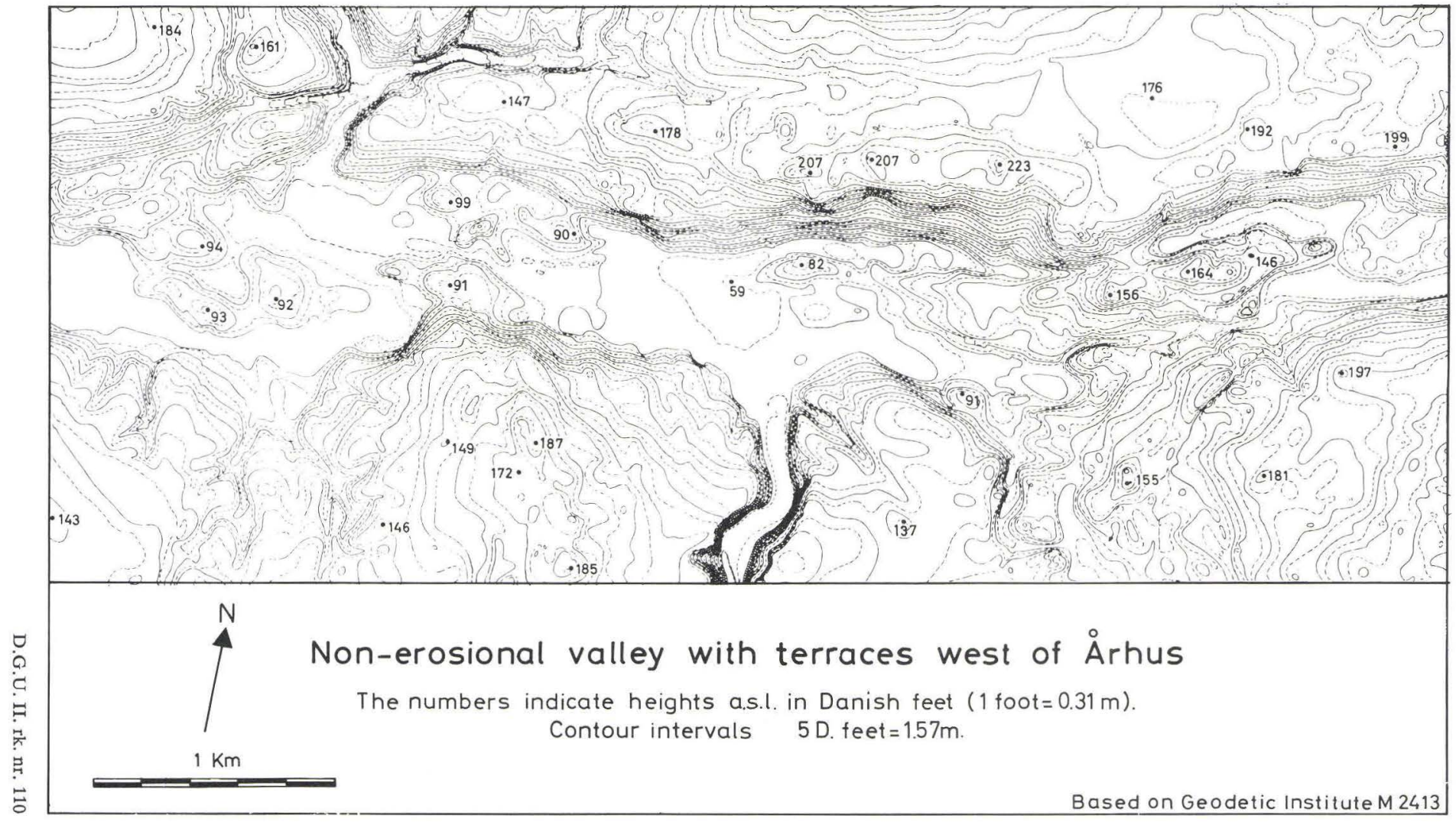


mammilar shaped hills. To ensure the present drainage it has often been necessary to dig or at least to deepen the passage through the thresholds.

\section{The »washboard « landscapes}

In considerable parts of the country the landscapes have a morphological structure which is roughly orientated from northwest to southeast. This is especially conspicuous in many regions as a consequent pattern of the elongated hills, which makes the landscape reminiscent of a washboard. However, the structure can also be observed in the trend of some valleys, but the "tunnel" valleys seldom fit this pattern. The plains frequently contain this structure in their general limitation and the border of the plains can show a splitting up into finger-like, parallel spurs following this NWSE structure. In the following only the first-mentioned form will be considered.

In fig. 8 a washboard landscape from the northern part of the island of Fyn is depicted. In the lower part of the figure the hills form a para-plain a little higher than $20 \mathrm{~m}$ a.s.1., but in the upper part of the figure the top level of the hills is variable. The hills have an obviously elongated form but show irregularities. This particular morphology continues southeastwards to the east coast of the island. In this direction the hills get higher and according to Madsen (1902) consist of a complex of till and sorted sand and gravel. In the area depicted (fig. 8), the map of the surface lithology indicates clayey till as the absolutely dominating sediment. Well-borings indicate however, that the hills have a very complicated sedimentological composition. In a gravel pit at Asum a flow till with slump folds (fig. 9) overlies sorted sediments of sand and gravel. From these observations the sediments are interpreted as belonging to an ablation complex.

Towards the northwest the washboard landscape (fig. 8) continues, but

Fig. 5. Contour map of a down-wasting valley. Note the terraces, the blind subordinary valleys and the fuzzy configuration of the contour lines. The valley is considered in the literature (e.g. Milthers 1948) to be a subglacial "tunnel"valley formed by water erosion. The lithological compositon of the landscape is extremely complicated, but it is dominated by sorted sediments. The occurrences of the different sediments, including tills, does not seem to bear any simple relationship to the morphology of the landscape.

In this paper the valley is considered to be a down-wasting valley, which has acquired its present appearance during the wasting of the Weichselian ice. In the surface of the subjacent Pre-Quaternary deposits is a valley which seems to have been eroded at the end of the Tertiary (Lykke Andersen 1973) and which may in some way have influenced the formation of the present valley. Copyright Geodetic Institute. 


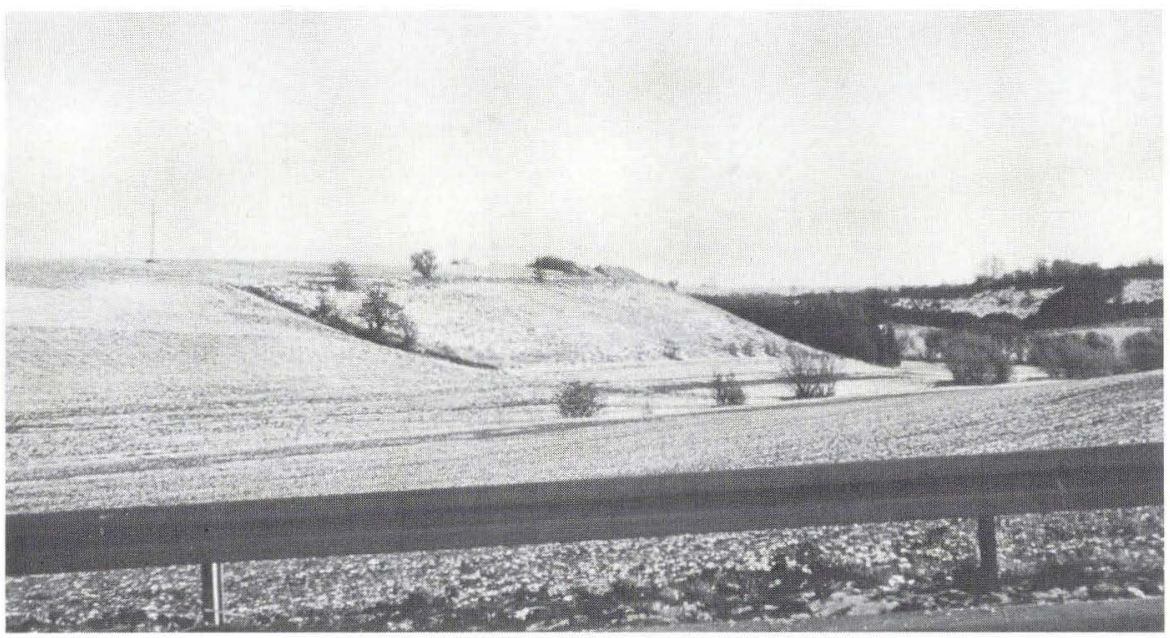

Fig. 6. In the areas north and northwest of Copenhagen, and especially in the region east of the village of Stenløse, the landscape is characterized by plains. In the plains are well-marked "tunnel"valleys, which often have a sharp upper edge. These shoulders can be seen in the photo. The plain in the foreground has the same altitude as that in the background.

with a lower relief. The hills contain a very compact till. A fabric analysis shows an orientation parallel to the elongation of the hill and dipping in both directions. This till is interpreted as a lodgement till. In the depressions are sorted and badly washed sediments.

\section{Synopsis of observations}

The morphology and sedimentology of the plains, the "tunnel" valleys and the washboard landscapes have been described and illustrated in this chapter. In the selection of localities it has been attempted to find some which show the characteristic features in a well-developed and clear manner. In this way the described examples show the range in the emphazised features. However, these features seem to have a much wider extension than that

Fig. 7. An ablation landscape with down-wasting valleys and plains. The hanging character of the tributory valleys indicates that the main valleys contained ice during the formation of the secondary valleys. The fact that it is possible to follow the altitude of the threshold of the hanging valleys and of the terraces in the main valleys out into the surrounding plains indicates a joint genesis. The irregularity in the plains can be ascribed to melting of former irregular occurrences of ice. 


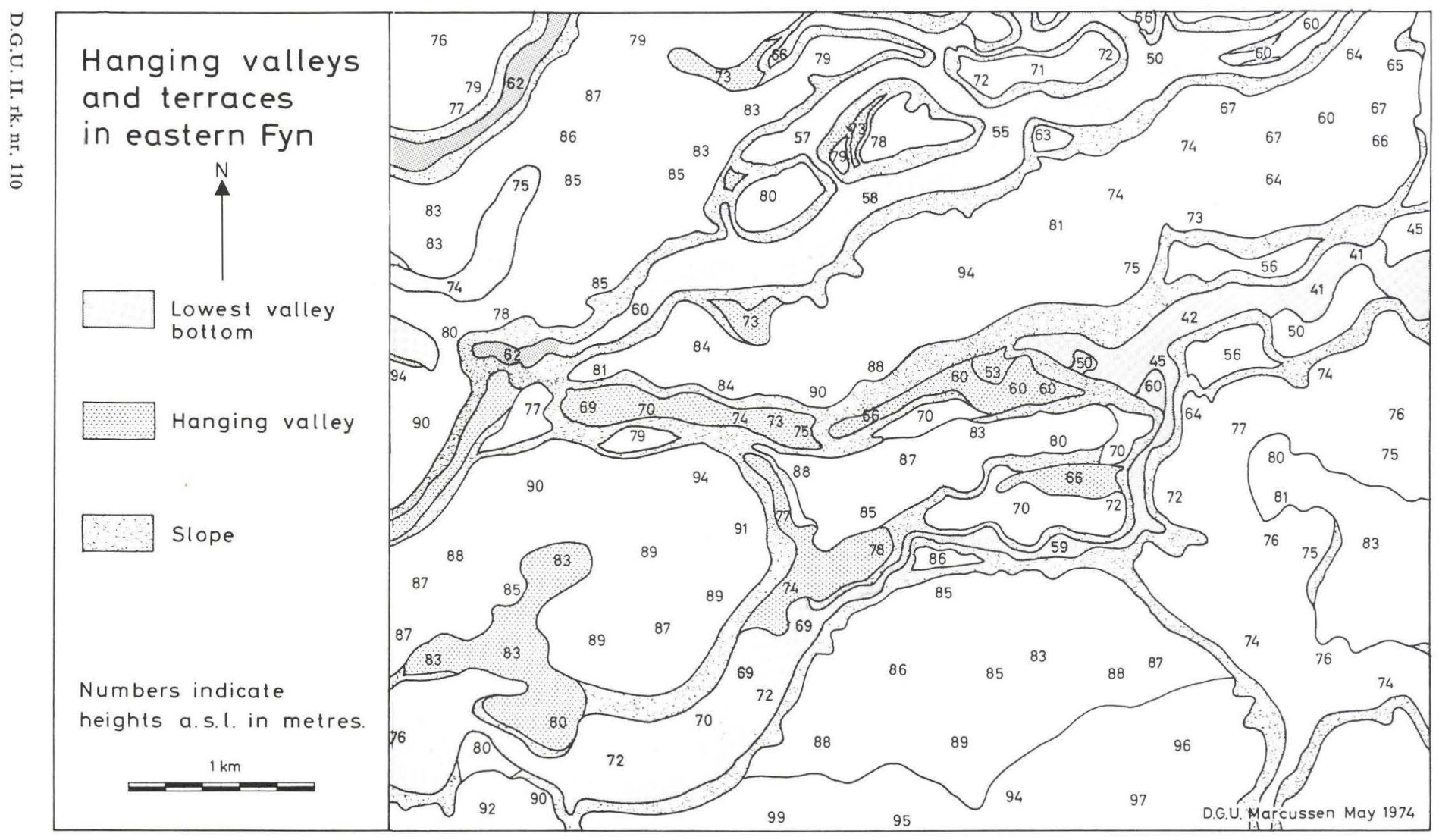




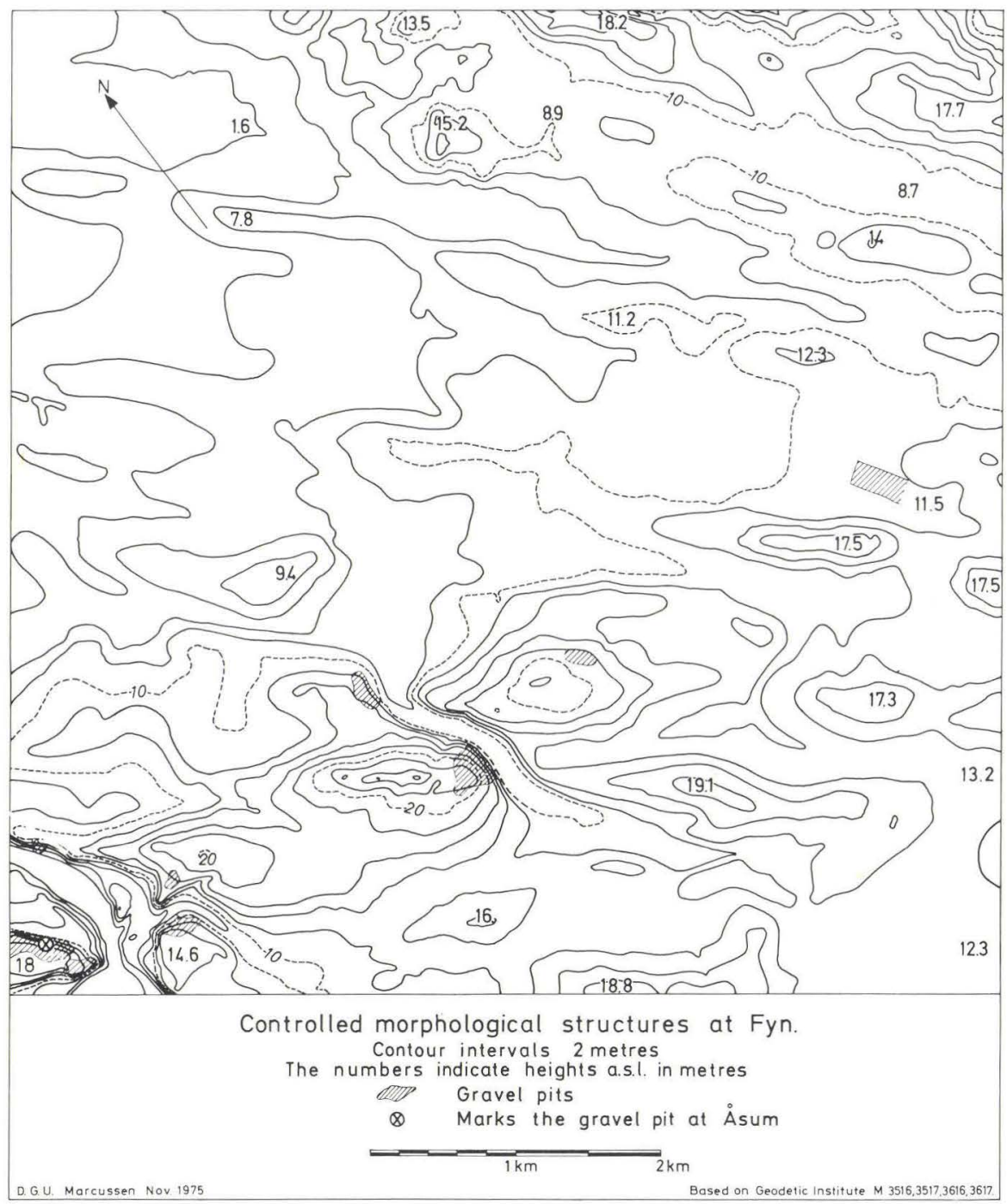

Fig. 8. The depicted washboard-like landscape is composed of sorted meltwater sediments and flow till. This lithological composition as well as the coarse morphology make these hills different from washboard moraines and De Geer moraines. The hills are interpreted as Thule-Baffin moraines. Copyright Geodetic Institute.

indicated by the figures. They are probably present in most parts of the country. Thus, K. Hansen (1975) has described the same forms as presented here in connection with a "tunnel" valley system in the central part of Jylland. 


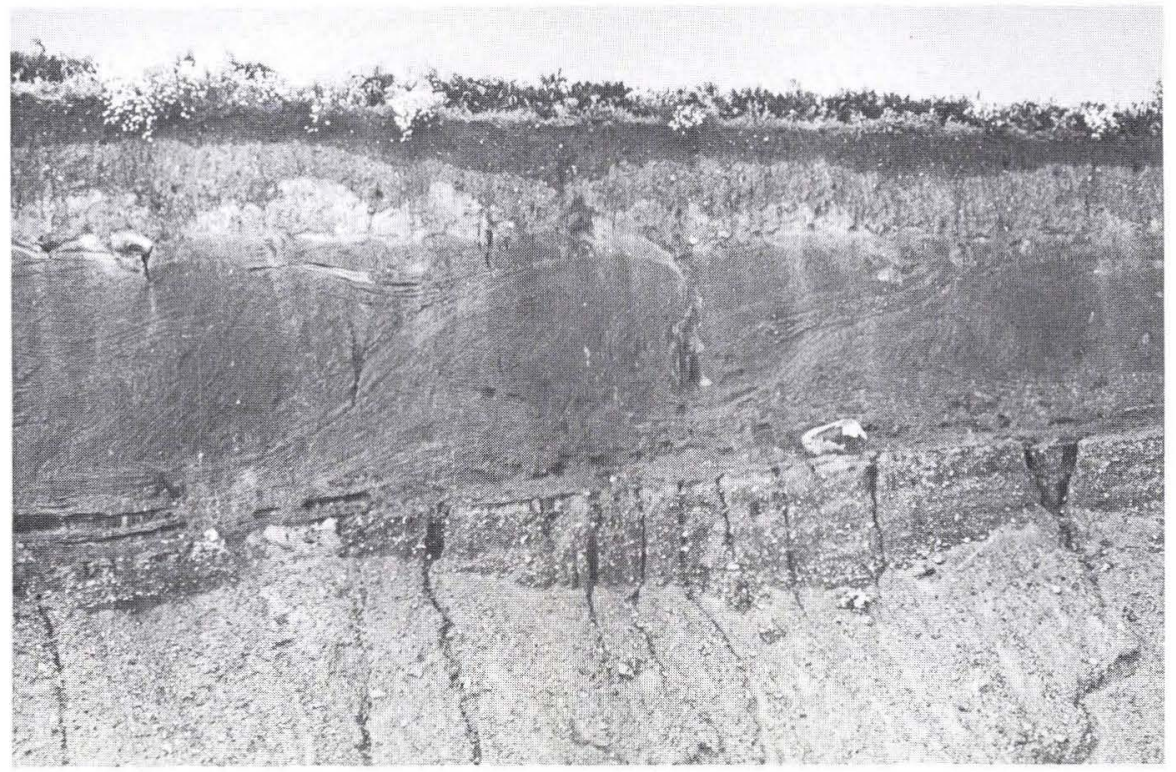

Fig. 9. A profile in the gravel pit at Asum (marked at fig. 8). The meltwater gravel in the lower half of the profile is overlain by a till, which at this location is about three metres thick. Notice the layering and folding of the till. The striated stones (discussed in the text) were situated around the surface of the meltwater gravel. The till is interpreted as flow till. Photo Sigurd Hansen 14.10.1942.

The general geological mapping and the very large number of registered boring indicate a distinct predominance of waterlaid sediments in the Quaternary glacial deposits (personal observation). Till occurs frequently as layers in the series of meltwater sediments. From localities where observations have been possible these tills most frequently show features which are considered to be characteristic for flow till (Marcussen 1973, 1975), and they are consequently interpreted as parts of ablation complexes. Till thought to have been deposited by lodging has also been observed in the country, but not as parts of the features discussed in this paper.

Plains can be observed in large areas. The plains appear with different altitudes in a step-like manner. The transition from one plain to the next is frequently steep. The most highly situated plains are typically rounded hills with steep sides. The plains appear in two ways; either as continuous forms (ortho-plains) with a slightly undulating surface and kettles, or as flat-topped hills having a constant top-altitude (para-plains). The plains frequently have a well marked edge to the "tunnel" valleys and sometimes it is possible to trace a plain into a valley as a terrace along the side or 
as hills out in the valley. The bottom profile of the "tunnel" valleys is uneven and considerable differences in height can be observed. Tributary valleys may be hanging and can be related to a terrace. One or all of these features can be observed in all the valleys mentioned as "tunnel" valleys by V. Milthers (1948).

Elongated hills often have a close relationship to plains, either as parts of a para-plain or as finger-like spurs at the rim of an ortho-plain. The elongated hills can also appear as independent forms but in contrast to the supposed ground-moraine forms (consisting of lodgement till) they contain meltwater sediments and flow till. 


\section{Discussion}

As mentioned in the introduction the processes connected with a glaciation can be divided into at least two different phases: The euglacial and the deglacial.

The first phase comprises processes related to the dynamic, living glacier ice and covers such phenomena as striation, drumlins, terminal moraines and deposits such as lodgement till and melt-out till (subglacial as well as supraglacial). Furthermore, tectonic deformations caused by movement of the ice must also be included here.

The other series of processes is connected with the wasting of the glacier ice. These processes will obviously be characterized by water activity to a very high degree. The extent of the resulting deposits will depend closely on the amount of material which was at the disposal for the water. It is consequently very important whether the glacier ice was clear or whether it contained debris. In both cases the melt-water will leave the glacier ice and create a sandur plain in the foreland. However, this uniformity will obviously come to an end in the glacier-covered area. The thawing of the debris-free ice will release only water until the thin, debris-rich bottom layer is reached. The resulting deposits can therefore be expected to be very sparse and will probably occur as sandur-like forms. This is not the case if the glacier ice contains debris. Such debris may exist not only in the sole of the ice; if compressive flow occurred in the glacier the material can have been raised high up over the bottom. Thus, during the thawing of the ice debris will be released in addition to the water. The wasting of glacier ice of this type may therefore be expected to result in specific deposits of a kind resembling kames and pitted sandurs. Tectonic deformations can be expected to occur in these deposits. The melting of buried ice will result in the collapse of the package of sediments over the ice. Slumping and thrusting will therefore take place and the possibilities of folding by squeezing has also been discussed (Stalken 1960). Although the melting ice does not take part in the general movement of the living glacier, ice flow may occur. The direction of such a flow will be controlled by local conditions. In this way the ablation deposits may also become deformed. The deposits considered in this paper frequently show tectonic 
disturbances. An analysis has not been made since several aspects concerning the origin of the phenomenon are unclarified and under discussion (e.g. Berthelsen 1974, Rasmussen 1975, Sjørring 1974); it seems likely to the present author that it should be most profitable to consider these problems in their entirety.

\section{Discussion of current concepts in the literature}

Flat areas showing mainly top layers of till have been described as "tillplains" in the Danish literature. However, these plains as they are mentioned by Ussing (1904) and V. Milthers (1948) can actually be divided into three essentially different groups.

The first group comprises smooth, rolling landscapes with a well-marked orientation of the low elongated hills. Lithologically these landscapes consist almost exclusively of a very massive clayey till, which may be interpreted as a lodgement till (Marcussen 1975). These landscapes are consequently considered to be ground moraine.

The second type of plain has more complex nature and will be discussed as the washboard landscapes on page 34 .

The third group of plains has no specific morphological structure besides the flatness. In this respect the plains are very like the plateaus described from Sweden (Hoppe 1952) and Canada (Gravenor 1955, Gravenor and Kupsch 1959, Stalker 1960, and Parizek 1969). Ridges along the rims of the plateaus have been described from most of these areas, but have not been observed in Denmark. Hoppe and Stalker interpret the plateaus as the result of sedimentation in subglacial cavities. It is hardly possible to apply this hypothesis to the plains presented in this paper because of the large dimensions of the forms and the step-like arrangement. Gravenor and Kupsch and Parizek are of the opinion that the plains were formed in the same way as kames. The plains represent depressions and hollows in the glacier ice in which released englacial material sedimented. This idea seems to fit with observations presented here and will be developed further in a following section.

Ussing (1904) and Milthers (1948) interpret the Danish plains as exaration features created beneath the advancing ice at some distance behind the terminus of the glacier. This hypothesis does not seem to be directly disproved by observations from recent glaciers. But on the other hand subglacial landscapes should be expected to show morphological forms reflecting a simple relationship to the glacier movement and to consist of a coherent lodgement till to at least some extent. The following observations are hardly consistent with the hypothesis of a subglacial origin of the 
plains occurring in Denmark: 1. The step-like arrangement of the plains. 2. The disintegration of the plains into minor hills with equal top altitude. 3. The relationship between the terraces in the valleys and the plains.

The plains resemble in many respects the deposits described in the Danish literature as ice-dammed lakes, which can be regarded as a type of kame since they show ice-contact features. The morphology of the plains is quite the same, but lithologically there may be differences which, however, are assumed by the present author to be insignificant from a genetic point of view. Till occurs frequently in the uppermost layer in these plains, but it appears in unconnected areas. At all investigated localities the till shows features indicating a supraglacial origin (Mertz 1959, Marcussen 1973, 1975). Since the plains include meltwater deposits and flow tills in the same way as kames, and since the two features have essential morphological characters in common it seems reasonable to imagine a similar genesis.

Flatness of a landform can usually be connected with fluvial activity, and Gripp (1954) therefore interpreted the plains as evidence of such processes during the deglaciation. On top of the down-wasting dead ice the erosional basis of the rivers was gradually lowered and the plains should represent abrasion terraces. This hypothesis explains many of the morphological features but seems to overlook the fact that the plains consist substantially of sorted sediments. A modification of Gripp's hypothesis by allowing accumulation to outweigh erosion has been proposed by Gry (1952). The hills in fig. 4 are interpreted by Gry as parts of a sandur plain deposited on the top of wasting glacier ice. This idea will be the basis for the approach put forward in the following section.

The valleys - Two types of valleys have been mentioned previously and will be discussed here.

The flat bottom in the river valleys consists of water sorted sediments and since these deposits are situated in the low parts of the landscape it is not necessary to imagine a topography different from the present during their deposition. But the recent, usually small stream can hardly be responsible for the formation of the valleys nor the deposition of the sediments. A much bigger drainage through these valleys may be supposed to have taken place at some time in the past. This implies conditions outside the valleys different from the recent. In this connection it should be natural to imagine the existence of areas of melting ice. In the Danish literature these valleys are termed extra marginal meltwater valleys and they are considered to have been formed during the melting of the last ice, before dense vegetation covered the landscape. As the river did not necessarily come from the margin of a glacier but can also have been derived from melting dead ice the term (extra marginal meltwater valley) seems to be 
too specific and may cause misunderstandings. It would be more natural to use the term river-valleys as suggested by Ussing (1907).

The formation of the "tunnel"valleys seems to be very complex, and different conditions and processes may have been involved. Since these morphological phenomena apparently form a feature of the Quaternary deposits, the processes of this period must have been active in their genesis. But conditions at the surface of the Pre-Quaternary deposits can obviously have been of importance in some cases. Lykke Andersen (1973) has observed a conformity between a "tunnel" valley (the one in fig. 5) and a valley in the surface of the subjacent Pre-Quaternary deposits. There is evidence indicating that erosion at the end of the Tertiary formed the valley in the Pre-Quaternary deposits.

However, fault activity which has caused a lowering of the Pre-Quaternary sediments underneath the present valleys has also been observed (Sorgenfrei and Bertelsen 1954, and Bull et al. 1976). The observations of Eemian freshwater deposits below the bottom of "tunnel" valleys (Lykke Andersen 1973, Bull et al. 1976: in both cases the age determination has been made by pollen analysis by Sv. Th. Andersen, DGU) indicate that at these places depressions existed in the landscape before the Weichselian glaciation. The possible influence of this on the glacier ice and glacial deposition will be discussed further in the following section.

In some contrast to the above, some observations have shown that the relationship between the morphology of the two surfaces (the recent and the one of the Pre-Quaternary deposits) can be very complex (Schrøder 1973) or apparently without any relationship (Stenestad 1976).

The observations of Eemian deposits in the sides of some "tunnel" valleys (Hartz and Østrup 1899, Hartz 1909, K. Jessen and V. Milthers 1928, S. Th. Andersen 1965) indicate that these valleys were formed in the Weichselian. The observations indicate furthermore, that these valleys were formed by erosion. This concept has been applied to most of the valleys in the areas in Denmark which are assumed to have been glaciated during the Weichselian. However, a depression in the deposits sedimented in a glacial environment is not necessarily an indication of erosion, but can also be a result of lack of sedimentation in an area in relation to the surroundings. Such a condition exists if glacier ice is buried and left during the deglaciation. Thus there seem to be at least two possible ways for the formation of the "tunnel" valleys; in the next chapter (page 36) a model for an interaction will be discussed. Before that, the current concepts in the Danish literature concerning the formation of the "tunnel" valleys will be discussed. As mentioned above, erosion is considered to be responsible, and this erosion is assumed to have been caused either by subglacial meltwater 
streams or by a complex of glaciers and rivers. In the following these hypotheses will be discussed in that order.

Ussing (1907), and many subsequent authors (K. Hansen 1971, gives a review) suppose a free penetration of the meltwater through the glacier ice. In the lowermost zones of the glacier the water came under great hydrostatic pressure due to the water columns in the crevasses. The water then moved as streams mainly along the interface between the glacier and the substratum towards the front of the glacier. During this passage the "tunnel" valleys were eroded. The supposed high hydrostatic pressure enabled the water to move indepently of the gravitation. In this way the water could also move upward; the maximum vertical distance registered in Denmark is 113 metres over a distance of 3 kilometres (K. Hansen 1971). However, it seems unlikely that an open hydraulic system with a steady influx of water and in a permeable material will be able to create such a pressure. K. Hansen (1971) comes to a similar conclusion.

Wright (1973) also supposes a subglacial water erosion to be responsible for the genesis of the tunnel valleys, but based on the assumption of a cold ice sheet. The temperature of the ice was below the pressure-melting point and the ice was therefore impermeable. Depending on factors such as local pressure conditions and heat flux from the ground, water under high pressure can exist in and under such a glacier (Boulton 1972 b). A pressure gradient will cause a flow of the water and therefore also the possibility of erosion. However, the situation is more or less unstable and with a decrease in pressure the water can freeze again. These events will take place some distance from the margin of the ice sheet and usually not in the terminal zone which will be cold because of the influence of the temperatures outside the ice mass.

It is possible that at least some of the Danish "tunnel" valleys were originally formed in this way, but during the wasting of the ice some new and characteristic forms have been added. These features will be discussed in a later paragraph.

Gripp (1949), Woldsted (1952) and K. Hansen (1971) discuss the hypothesis that long narrow lobes jutted out from the front of the ice sheet and excavated the valleys. The first two authors refer to investigations of alpine glaciers, but as mentioned previously it appears to be unreasonable to compare the glacier ice in the Danish area with temperate alpine glaciers. Furthermore, the glaciological conditions permitting the splitting up of the ice into glacier tongues and the presence of a gradient sufficient to enable the movement of these glaciers are an unexplained phenomena.

Woldsted (1952) and Berthelsen (1972) discuss the possibility of erosion by streams in front of the glacier ice, which later advanced to the valley.

3 D.G.U. II. rk. nr. 110 
Some of the outline hypotheses give possible mechanisms for the formation of the valleys, but since the envisaged processes are considered to occur in the euglacial phase an extensive discussion lies outside the scope of this paper. Besides, the hypotheses do not give sufficient explanation of characteristic features in the valleys and may therefore only be regarded as possible parts of a more comprehensive hypothesis. It is a general feature that traces after erosion are negligible or even lacking in the valleys, and the existence of hanging tributory valleys related to terraces and plains outside the valleys are in conflict with a hypothesis based exclusively on erosion. In the following section (page 36) a new approach will be proposed which attempts to give an explanation of these last mentioned features.

The washboard landscapes - Landscapes with a low relief and with distinct elongated hills can be divided into two types.

The first type of washboard landscape is morphologically very simple. The hills have a straight, cigar-shaped form and they are low; only a few metres higher than the interjacent depressions (Marcussen 1975, fig. 5). The longitudinal profile may have one (A-hills, Marcussen 1974) or more (B-hills) tops. The hills vary in horizontal dimensions, but a common range is $2-5 \mathrm{~km}$ long and a breadth of about 0.5 to $1 \mathrm{~km}$. The A-hills in Fyn are on average 1.5 kilometres long and 300 metres broad. Sedimentologically these hills consist of a very compact clayey till, which may be regarded as a lodgement till. Fabric analyses show a preferred orientation parallel to the long axis of the hill and dipping in both directions. This may be interpreted as a b-orientation caused by a compressive flow in the glacier ice (Marcussen 1975, fig. 2) moving from the northeast. Hills of an intermediate form included in the morphological type called B-hills, may also have such a composition and may therefore be interpreted in the same way as the A-hills. Landscapes made up of deposits of this type are very seldom and have only been observed at a few places in the country, including parts of Lolland (fig. 14 and Marcussen 1975) and an area northwest of the area depicted in fig. 8. Since the till forming these "plains" has been interpreted as a lodgement till, this morphological element will be considered to be groundmoraine. These landscapes consequently represent the euglacial deposits and will therefore not be discussed any further in this paper.

The second type of washboard landscape is of widespread occurrence and can be observed in many parts of the country. These landscape consist characteristically of a mixture of till and melt-water sediments in contrast to the above-mentioned landscapes. The morphology is a little more complicated although the elongated form of the hills is still well-marked (fig. 8). 
The longitudinal profile has two or more tops. These B-hills may be larger than the A-hills (8-10 kilometres long, up to about one kilometre broad) and frequently they also rise higher (10-15 metres or even more) over the interjacent depressions.

No distinctions have been made between these two types of landscapes in the literature dealing with the Danish area. The elongated hills have been interpreted either as drumlins or as deposits from the front of the ice.

The area depicted in fig. 8 is described by V. Milthers $(1928,1948)$ and Smed (1962) as a till plain with drumlins. But the gradual change from the isolated, individual hills in the upper part of the figure to hills which form a part of a broken plain (a para-plain) consisting of ablation sediments contradict the hypothesis that the hills are drumlins. Furthermore, the area (fig. 8) continues towards the northwest in a landscape consisting of lodgement till, which indicates a direction of flow in the ice perpendicular to the hills. Finally, if this landscape indicates a drumlin pattern it is difficult to understand why this pattern can unmistakably be observed towards the south and southwest as far as the outer limit of the Weichselian ice sheet in northern Germany (personal observation).

In support of the drumlin hypothesis, S. Hansen (1942) described striation of some blocks situated around the base of the till depicted in fig. 9 . Faint striations roughly parallel to the elongation of the hills have been observed on a little more than half of the stones. Unfortunately the descriptions of the setting of the stones in relation to the till and the meltwater gravel is incomplete. Concerning the till, Hansen states that there is a discontinuos horizontal occurrence and a deficit of blocks in the upper part. Considering the available data it seems more reasonable to interpret the stone horizon as the result of sinking of stones to the base of a water soaked flow till and the striations to be a result of scraping in connection with a flow. Similar conditions have been described previously (Marcussen 1973). It is therefore concluded that the hypothesis of a genesis as subglacial drumlins seems to be founded on debatable arguments.

Madsen (1902 p. 83) considered the hills in fig. 8 "to have been formed at or near the ice border during the deglaciation" (translated). Hammermüller (1907) and Haarsted (1956) interpreted comparable hills in the islands of Lolland and Møn, respectively, in the same way. Elongated hills arranged as subparallel ridges in the landscape have been described as washboard moraines (Mawdsley 1936, Elson 1953, 1957) in North America and as De Geer moraines (Hoppe 1948, 1957, 1959) in Sweden. These deposits seem to consist exclusively of lodgement till and are consequently considered to have been formed subglacially. Furthermore, they are much smaller and lie much closer together than those discussed from Fyn. In this 
way essential differences exist, especially in the composition, and another genesis may have been involved. To the observed complex lithological composition correspondance complex sedimentological environment which can be of the type observed at melting subpolar glaciers. The hills in fig. 8 may therefore be interpreted as a kind of the Thule-Baffin moraines described by Goldthwait (1951), Souchez (1966) and Hooke (1970).

\section{A new approach}

From the preceding discussion it appears that none of the mentioned hypotheses of the formation of the "tunnel" valleys and the plains seem to give a fully adequate explanation, covering both the genesis of individual morphological elements and the close relationship between the valleys and the plains.

If the Weichselian ice sheet was of the subpolar type and therefore contained debris to a considerable extent, it will be obvious that deposits older than the deglaciation phase may be hidden under a blanket of sediments deposited during the wasting of the ice. The hypothesis proposed in the following does not exclude an origin of the valleys prior to the deglaciation, but it tries to explain the genesis of distinctive morphological features in the valleys and in the surrounding landscape as we see them to-day.

During the deglaciation the solid ice was altered to water and the icebound material in the lower part of the ice sheet gradually released. The water-rich environment affected the supraglacial material to a varying degree and in this way various types of flow till and meltwater sediments were created. Morphologically the sedimentation was controlled by two factors: the water and the subjacent and surrounding ice. Sedimentation by water will give rise to a tendency to develop horizontal bedding, which will naturally be reflected as a flat surface to the deposits. The ice will form the basins for sedimentation and can in this way underpin the deposits. By further melting of the ice depressions with steep slopes may be formed. The melting of the ice underneath the flat deposits will cause both a break up of the surface and disturbances of the setting of the sediments. These processes can repeat themselves many times during the total wasting of the ice and much of the early deposited sediments will be reworked and incorporated in later deposits. The outlined supraglacial environment is very dynamic and it seems at first sight to be influenced by contingencies, but it is under all circumstances controlled by strong forces.

The basic assumptions for the interpretation of the morphological elements considered here can be summarized in the following way. The plains were deposited as supraglacial sandur plains (sensu lato) and the "tunnel" 
valleys were formed as elongated kettles in the plains. However, the valleys may have had an earlier history as erosional valleys or perhaps as tectonic features in the Pre-Quaternary deposits.

The flat topped, elongated, narrow hills in the southeastern corner of the map fig. 2 have been interpreted as crevasse fillings (Andersen 1931) deposited by meltwater running from southeast to northwest, parallel to the long axis of the hills. Andersen is of the opinion that the meltwater stream suddenly changed direction towards the north and north-northwest, and then followed the braided river system. His argument for this was some small hills consisting of meltwater sediments. The altitude of the flat tops of these hills (except for two which reach 28 and $29 \mathrm{~m}$ a.s.1.) is 23-24 metres a.s.1. and this is a characteristic level for large areas in the region as shown at fig. 2. A surface mapping of this plain indicates that sorted sediments are the main constituent. Andersen seems to have overlooked that the elongated hills continue distinctly towards the northwest as well-marked hills built up of meltwater sediments. The altitude of the tops of these hills is between 45 and 55 metres a.s.1. A minority are lower than that, but do not differ morphologically or lithologically from the others. This row of hills can be followed for about 25 kilometres. At the northwest end the hills attach to a large plain consisting mainly of well-sorted, fine sediments. Occurrences of till in the plain have been investigated and they show features characteristic of flow till (Marcussen 1975). If it is accepted that the elongated hills to the southeast are part of a drainage system as described by Andersen (1931) it seems illogical not to include the plain in this system. Consequently, the whole system of elongated hills can be regarded as crevasse fillings (Flint 1928 a), a kame ridge (Niewiarowski 1957), or a linear disintegration ridge (Gravenor and Kupsch 1959) and the plain can be compared with the terraces and plateaus described by Fint (1928 a, b, 1929, 1933, 1942), Jahns and Willard (1942), Rich (1943), Gry (1952), Niewiarowski (1957), Gravenor and Kupsch (1959), Mackay (1960) and mentioned by Richter (1937). In this way the plain is considered to be a lake deposit or maybe expressed in a better way a supraglacial sandur. This interpretation is also mentioned by King (1975). K. Hansen (1975) consider some similar highly situated plains in the central part of Jylland to be normal sandurs, but older that the last glaciation.

Apparently similar deposits with a flat horizontal top have been described from a deglaciation area in Alaska as a colapsing kame terrace (McKenzie 1969). In that situation the buried ice was observed under a cover of 3 to $6 \mathrm{~m}$ of debris. Observations by Price (1969) from Iceland also support the proposed hypothesis.

The overall sedimentological composition of the other plains is equivalent 
to that of the plains discussed above. It can therefore be argued that the other plains have a similar genesis. The existence of a braided river system in one of the plains strengthen this argumentation. Special conditions during the sedimentation account for the irregularities from the absolute level. Melting of subjacent ice lowered and disintegrated the plains, as described for pitted sandurs (Ussing 1903, Thwaites 1926, Rich 1943, Price 1969, 1971). Ascending forms can have originated in different ways, as for example as flows of material from more highly situated areas, or by erosion.

The flatness and the constant altitude of the individual plains in a region is surprising if the deposition exclusively took place on top of a continuous layer of ice. The most obvious explanation seems to be the existence of performations through the ice, which permitted the supraglacial deposits partially to rest on the substratum of the ice sheet. By a widening of the basins and a lowering of the ice the steplike arrangement of the plains may possibly have been established.

Depending on local conditions, the deglaciation deposits will be of varying appearance and size. The most prominent local factor is probably the amount of debris in the ice. If much debris is released during melting, large forms of the type shown in fig. 2 can be expected. In contrast to the meltwater, structures in the glacier ice (zones of shearing and crevassing) will only have a slight chance of influencing the morphology of the deposits. With a decreasing amount of debris the influence of the ice on the forms of the deposits will be bigger. In fig. 3 and over large areas of the ablation landscapes in Lolland (fig. 14) the deglaciation deposits have linear forms which are interpreted to have been controlled by structures in the glacier ice. In the washboard landscapes fig. 8 the morphology of the deposits is dominated by the glacial structures and only slightly by meltwater.

Subordinary features in the ice sheet can also influence the deglaciation deposits, but this will presumably generally occur in co-operation with the above mentioned glacial structures. In the investigated areas such a feature is the tendency of glacier ice to form subcircular hollows (Sharp 1947). Typically the shape varies a good deal from the ideal form (fig. 4). The resulting hills may be arranged in the landscape as irregular rows. These rows are parallel to (in fig. 4), perpendicular to (e.g. in the island of Langeland) or form a 45 degree angle (on the peninsula of Hindsholm) to the widely distributed morphological structure from northwest to southeast. Similar structural arrangements have also been observed in Canada by Gravenor and Kupsch (1959).

In considerable areas of the island of Fyn, rounded but often irregular hills show a tendency to be arranged in rings. The diametres are 3-5 kilometres and normally parts of the rings are lacking. The hills consist of 
ablation sediments, and some of them are among the highest parts of the landscape. Major structures in the ice sheet are probably responsible for these features. Two systems of shear planes exist in glacier ice which are respectively parallel to and perpendicular to the direction of movement. These structures may be reflected in the orientation of the above-mentioned rows of hills and further, in the general orientation of the elongated hills in the landscape. In addition to these features a system of vertical crevasses in the lower part of the ice sheet may appear with an angle of 45 degree to the ice movement (Embleton and King 1969). This gives an explanation for the above observed row of hills. The rings are probably the result of interaction between these three structures in the ice sheet (Aartolahti 1974).

Since the deposition is considered to have occurred on the top of the wasting ice, bloks of ice may be left in the sediments and the melting of these can be expected to form depressions in the flat landscapes. Depending on the size and shape of the ice bodies, and the local meltwater activity the disappearance of the ice may produce different results. In the most simple case a kettle will be formed, but if this development takes place over a large area where the thickness of the ice varies a complicated hilly landscape will appear. During the wasting erosion and sedimentation can occur in connection with the depressions and in this way hanging valleys and terraces may develop. Ussing (1907), Flint (1929), S. A. Andersen (1931), Jessen (1935), and K. Hansen (1975) describe and discuss these processes.

The wasting of the ice sheet as outlined above has many features in common with the deglaciation in Canada as described by Gravenor and Kupsch (1959). In similarity with their observations, it seems possible also in Denmark to demonstrate two groups of deposits. The deposits appearing in a simple linear pattern are termed controlled and interpreted as remnants of structures in the ice sheet connected with the flow. The well-marked structures in fig. 2, 3 and 8 are interpreted as controlled forms while the plains with no well-defined pattern in the horizontal plane (in the figures 2, 3, 5 and 7) are considered to correspond to the uncontrolled forms in Gravenor and Kupsch.

The deglaciation deposits form a cover over the sediments and structures originated by the active ice, and only if this cover is thin or lacking is it possible to recognize them. In fig. 3 a partly uncontrolled plain superimposes elongated hills, which are considered to represent sub- or englacial deposits. An attempt is made in fig. 10 to illustrate the genesis of the area in fig. 3 . In the region in which the island of Lolland is situated ablation deposits are rather sparse and the subglacial deposits are often visible (see fig. 14).

The presented observations strengthen the hypothesis that the Danish 


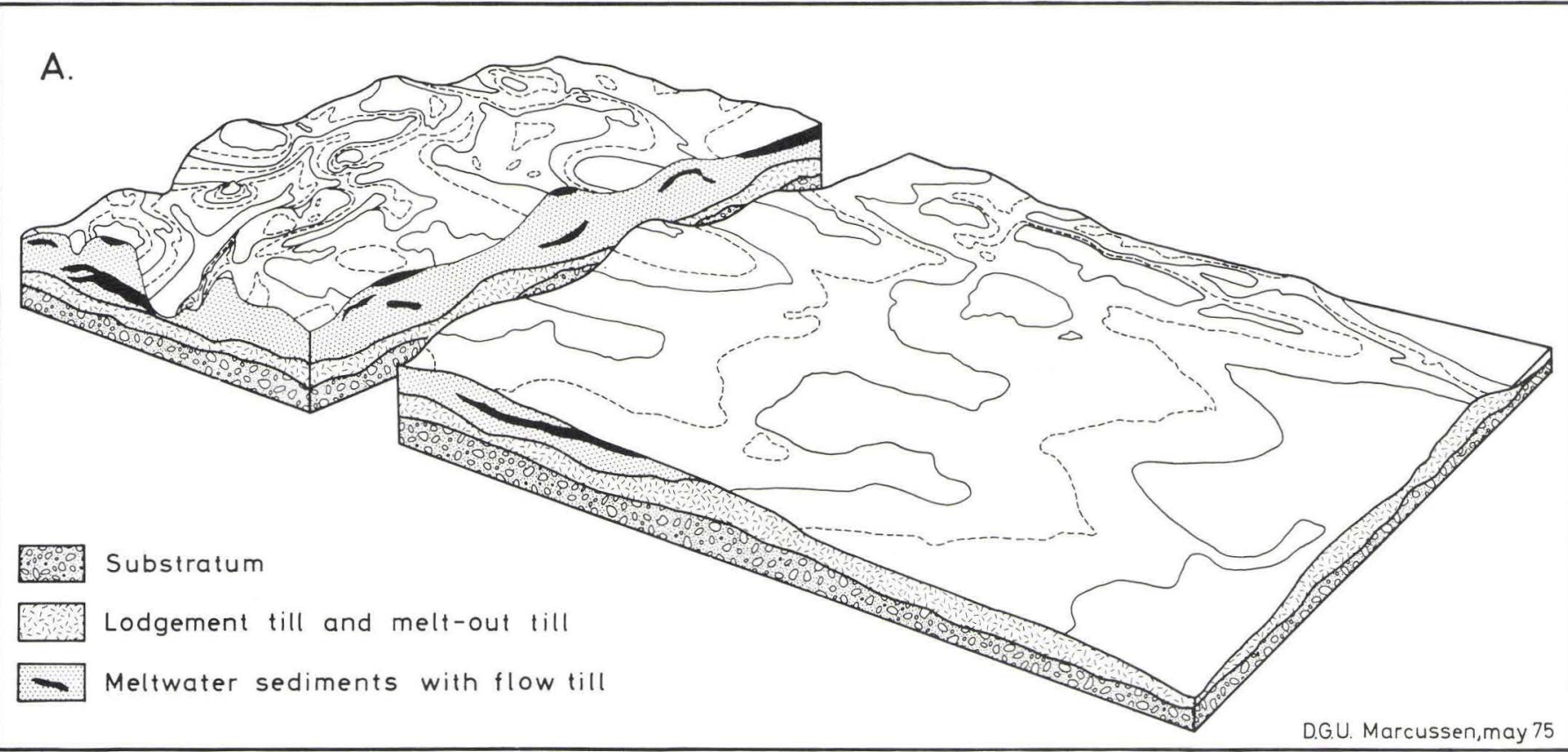

Fig. 10. Block diagrams sketching the landscape depicted in fig. 3 .

A. The landscape as it appears to-day. The lines indicate the contour lines. The setting of the ablation sediments, consisting of sorted material and flow till, is only suggested. Considerable disturbances can be expected in this formation.

$\vec{\circ} \quad$ B. A hypothetical model of the landscape during the deglaciation. 


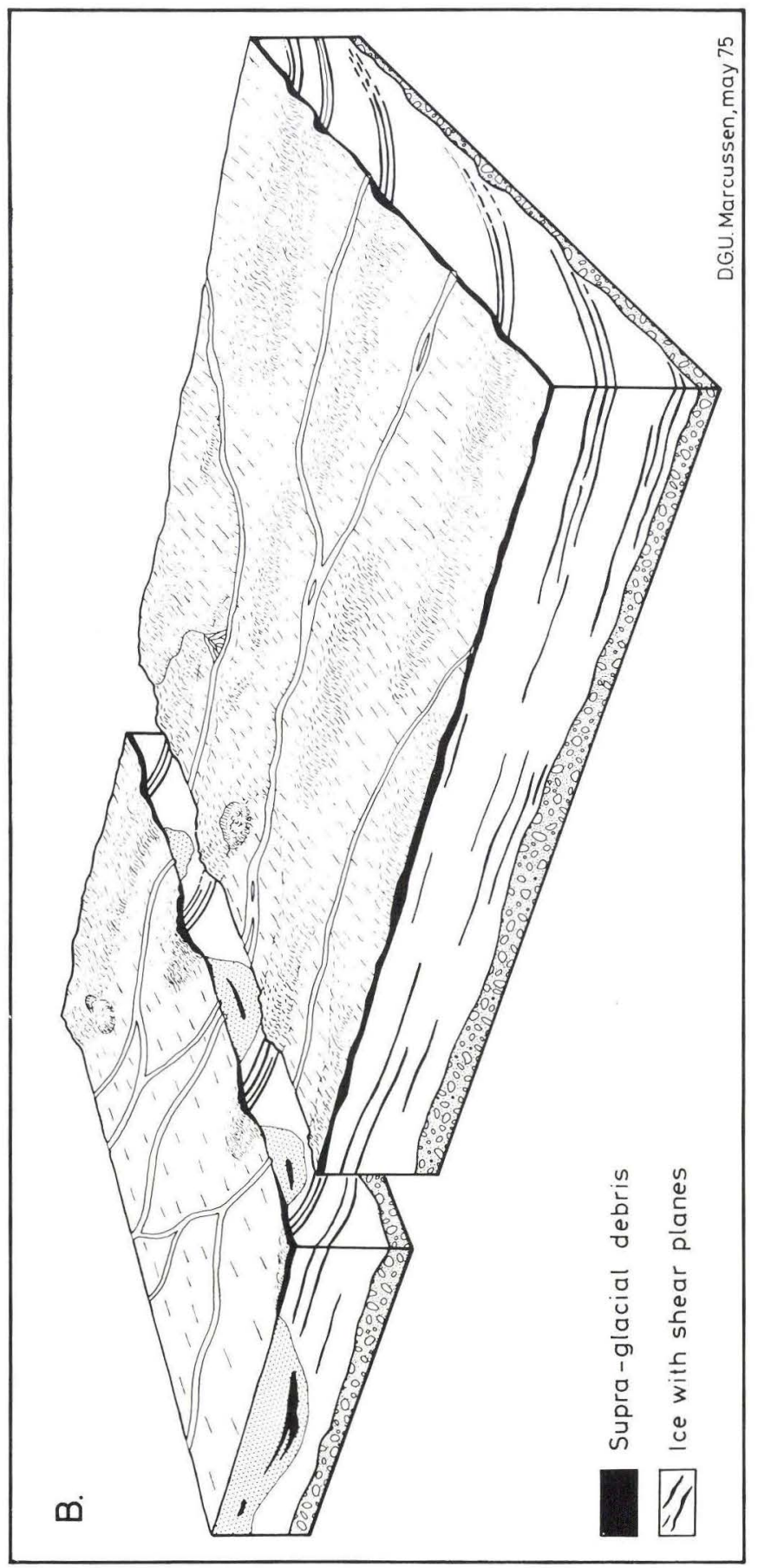

D.G.U. II. rk. nr. 110 
area was covered by an ice sheet in late Middle Weichselian. Furthermore, they indicate that the disappearance of the ice sheet did not occur as frontal wasting, but as area wasting in agreement with observations by Flint (1929), Rice (1936, 1937), Goldthwait (1938), Rich (1943) and Boulton (1972 a). However, these authors have investigated valley glaciers and some adaptation to ice sheet conditions can naturally be expected. The origin of plains at successively lower levels can be observed in lateral positions in recent glaciers. If this development is combined with deep hollows in the ice sheet it opens the possibility for the genesis of the observed "plain pyramids" in the Danish landscapes. In the following chapter this hypothesis will be discussed generally.

The location of the most highly situated embryonic plains and the deep "tunnel" valleys can possibly be related to differences in the thickness of the ice mass. But since the surface of the ice sheet was probably rather even, these differences may have been caused by inequalities in the surface of the substratum. Thus a relationship between Pre-Weichselian valleys and "tunnel" valleys has been demonstrated in some cases, but indications of the opposit have also been found. It can therefore not be excluded that subglacially created depressions may have influenced the ice thickness. A relationship between the high areas in the landscape and areas in which the surface of the Pre-Quaternary deposits is rising does not immediately appear to be present. But the topography of the Quaternary deposits before the last glaciation is unknown and perhaps the reason should be searched for here. Another possibility is that changes in the lithology and consolidation of the Pre-Quaternary sediments resulted in horizontal variations in the amount of incorporated material in the ice. The whole concept appears to be complex and must be followed up by further investigations.

It has been attempted, as far as it has been possible, to support the hypothesis presented here with observations from recent glaciers. Since most of these studies are mainly concerned with the morphological appearance of the deposits, it has been natural to attack the glacial deposits from the past in the same way. The sedimentology of the considered deposits has in a similar manner been related to investigations of recent glaciers (Marcussen 1973, 1975). The two sets of observations supplement each other and they form the basis for the concept of large, continuous sedimentational units formed during the wasting of the ice. The presented hypothesis justifies detailed analyses of the sedimentary structures. Such analyses can contribute to a description of the sedimentary basins of the surface of the down-wasting ice. 


\section{Area wasting of a continental, cold ice sheet - A model}

It is tempting to try to synthesize the presented ideas and observations into a model for the deglaciation sequence of the Weichselian glaciation in the Danish area. Such a model will naturally imply generalizations, and it is therefore less complicated and indicates fewer variations than nature itself. The model will like the rest of the paper, be based on the sedimentology and morphology of the deposits.

Glaciological considerations make it probable that the supply of ice to large areas of the ice sheet decreased successively and that these parts of the ice sheet changed to stagnant and gradually to dynamically dead ice. During the thawing the material included in the ice was released onto the surface. As the wasting continued considerable quantities of debris were gradually built up. Depending on the local situation the material could be left untouched by the meltwater or be washed and transported by rivers. All transitions between these extremes are of course possible. To judge from experience from recent glaciers, the rate of the wasting was very differentiated because of variations in the occurrence of debris in the ice and because of secondary changes in the distribution of debris on the surface of the ice.

To try to illustrate the complicated morphogenetic and sedimentological processes during deglaciation seems at first to be hazardous because of the highly changeable environment. Nevertheless, an attempt will be made. The model presented in fig. 12 considers mainly the large features, and many minor ones are omitted. Boulton (1968, 1972a) describes such features in detail. In fig. 12 the suggestion of layering in the deposited sediments is merely an indication of zones with undisturbed and disturbed bedding. In the collapsed zones the tectonic changes of the setting of the sediments can be of varying dimensions. Thus even disturbances of a large size observed in Denmark have been interpreted as the result of such processes (Jensen 1974).

The active agent during deglaciation is the meltwater. The sediments are sorted, transported and deposited by the water as in other river systems. But besides this it is possible that sediments move by flow movements (e.g. flow till) or by mass movements. Thus water has a predominant influence on the morphology and the structure of the deposits. However, since the 


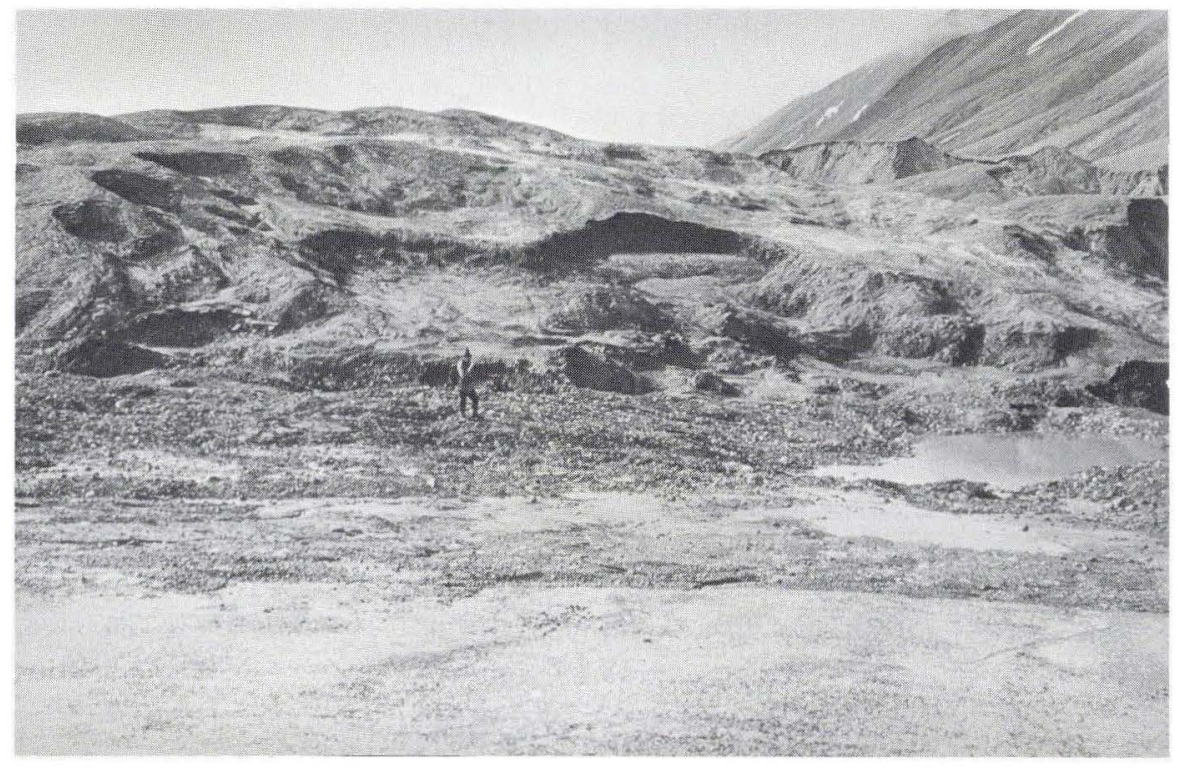

Fig. 11. Ablation sediments resting on the terminal part of Uversbreen, Vestspitsbergen, Svalbard. The photo is taken from the glacier towards the terminal zone. The environment is very unstable (notice the many landslides) because of the melting of the subjacent ice. Sorted sediments deposited in running and stagnant water occur in a complicated manner together with diamictic sediments from mudstreams.

Photo July 1975.

deposition occurs in close relation to the thawing ice, features within the ice sheet will also affect the deposits. Zones in the ice with differences in the content of debris occur parallel to the front, and Goldthwait (1951) has demonstrated that after wasting of the ice this feature can result in low elongated hills parallel to the front. Such rows of hills have been named Thule-Baffin moraines after the location where they were first described, and the morphology depicted in fig. 8 is interpreted as this type of deposit. Features in the glacier ice may obviously also influence the supraglacial drainage pattern and the meltwater streams will frequently be parallel to the structures. The esker-like ridge on the lower right side of fig. 2 has been interpreted as being controlled by a front parallel structure in the ice sheet. The degree of control over the streams may frequently vary, partly because a stream will sometimes have to cross the structures to reach more lowlysituated regions, and partly because the structures may be more weakly developed in some areas so that the stream behaves in a way characteristic of rivers. Examples of this type have not been depicted in this paper, but can be observed in Fyn and Falster. 
Besides the elongated forms more rounded forms also exist. The origin of these features in the ice is unclarified. But if a hollow once is created the further development seems fairly explicable. The difference in density between water and ice will create sufficient pressure in lakes deeper than 100 metres (Glen 1954) to keep them open and even to enlarge them. Any thermal conduction from the water will magnify this affect. Therefore, if an adequately large hollow is established in wasting ice it will not close and it will even be enlarged at an increasing rate. This process is additionally intensified by the fact that the sheltering cover of debris in the vicinity of the lake will have a tendency to move down into the lake and thus increase ablation in the surroundings. Under favourable conditions the lakes will consequently be filled up with ablation deposits. Because of ablation the general level of the ice surface will gradually be lowered, and sedimentation in a certain basin will therefore stop if the basin does not participate in the lowering. This will occur if the sediments protect the subjacent ice from ablation, or if the sediments rest on the substratum of the glacier ice. In the first case it seems probable that the sediments may later on be exposed to meltwater activity and thereby be redeposited to a greater or lesser extent. On the other hand, if the sediments rest on the substratum they will remain stable and only be exposed to normal erosion. It may be concluded that only deposits which penetrate the ice will be preserved in a recognizable form. Irregularities in these deposits, either morphological or structural, may be remnants from the early phases when deposits rested on the ice.

The diagrams in fig. 12 a-f give a greatly simplified picture of the downwasting process and this will be commented briefly. In fig. 12a thawing has worked for some time and debris has been released at the surface. The uneven distribution of this dark and isolating material will cause a differentiated wasting, and the surface will become irregular. This effect will be intensified by river erosion and a topography which has been compared to a karst will develop (Gravenor 1955, Clayton 1964). A characteristic feature is funnel-shaped sink-holes (Russel 1891, 1897, Cook 1946, Reid and Clayton 1963 and Clayton 1964) filled with water. Material from the surroundings will flow into the holes, and after the disappearance of the ice and inversion of the topography, they will form hills which are described as Prairie Mounds (Gravenor 1955), circular disintegration features (Gravenor and Kupsch 1959) and in Denmark as kames and plateau-hills (Milthers 1948). The highest parts of the pyramids formed by the plains are small hills of the type just mentioned. Sink-holes are therefore considered to be the embryonic structures, and the following development in the model fig. 12 follows the ideas presented in the previous chapter. 
The dominant morphological features in the presented model are the plains. Plains formed during a deglaciation are not a new phenomenon in the general concepts of glacial geology. From Canada flat-topped hills have been described as moraine plateaus (Gravenor and Kupsch 1959) and were considered to have been formed during the wasting of the glacier ice. Morphologically as well as lithologically the plateaus seem to be very like the plains described in this paper. Since these deposits do not show any relationship to the flow pattern structures in the glacier ice, they have been named uncontrolled disintegration features by Gravenor and Kupsch (1959). Comparable deposits have evidently been observed in areas east of the Baltic (Markus 1930) and in Poland (Niewiarowski 1959, 1963a, 1965 with a comprehensive reference list, and Klajnert 1966). In the northern part of West Germany landscapes with similar features have been described as Toteislandschaften (dead-ice landscapes) or Niedertaulandschaften (downwasting landscapes) by Gripp (1964). Since the latter name characterizes the main process in a reasonable way, it is maintained and the plains will thus be termed down-wasting plains.

In fig. $12 \mathrm{e}$ the wasting has been in progress for so long that the ice sheet has disintegrated into isolated masses. The thawing of these ice blocks will cause depressions in the landscapes. The form and size of the depressions will obviously depend on the shape and dimensions of the individual ice masses. Rounded ice blocks will give rise to kettles while elongated blocks may cause depressions in the form of valleys. The elongated form may be the result of different conditions such as the preglacial topography, subglacial erosion by water or ice, or internal structures in the ice sheet. To avoid confusion with real erosional tunnel valleys, it is suggested that these valleys be termed down-wasting valleys.

Vertical walls of clayey till with a thickness of up to a few metres are rather common in esker-like meltwater deposits in Denmark. Gripp (1964) interprets them as the result of the squeezing of the subjacent till into the

Fig. 12. A hypothetical model for the area wasting of a continental ice sheet containing considerable amounts of debris in its lower parts. The deposits from the first phase of the wasting can not be identified morphologically. This will not be possible until the deposits are stabilized by resting at the basement of the ice sheet. The perforation seems to start in a more or less circular hollow. During the subsequent wasting the morphology of the deposits may either continue as rounded to irregular forms, or may be marked by the structural pattern in the glacier ice. This pattern will be a result of the flow in the ice sheet and it will show up as zones parallel to the front and perpendicular to this direction (in some cases also with a 45 degree angle to the front).

For further explanation, see text. 


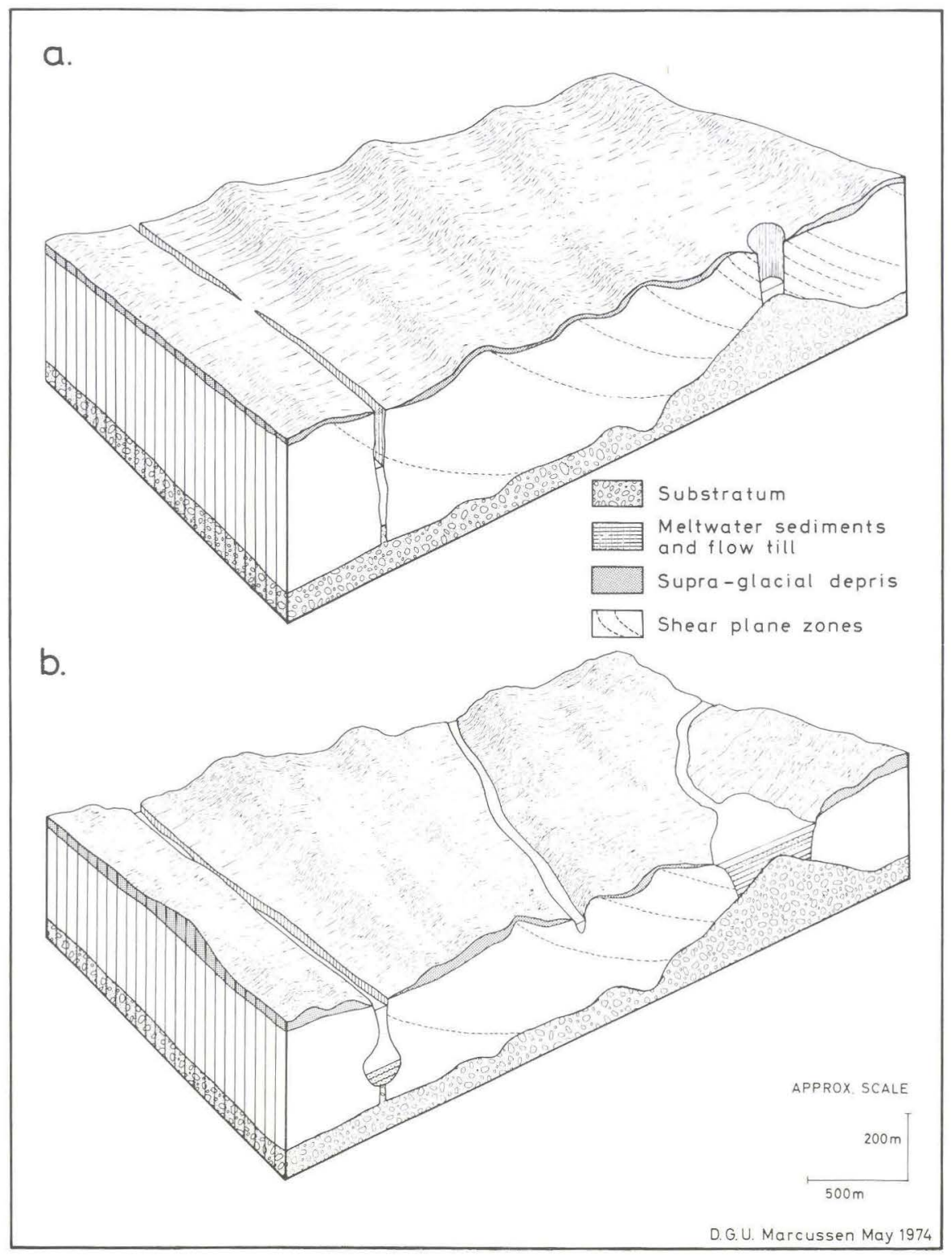


c.

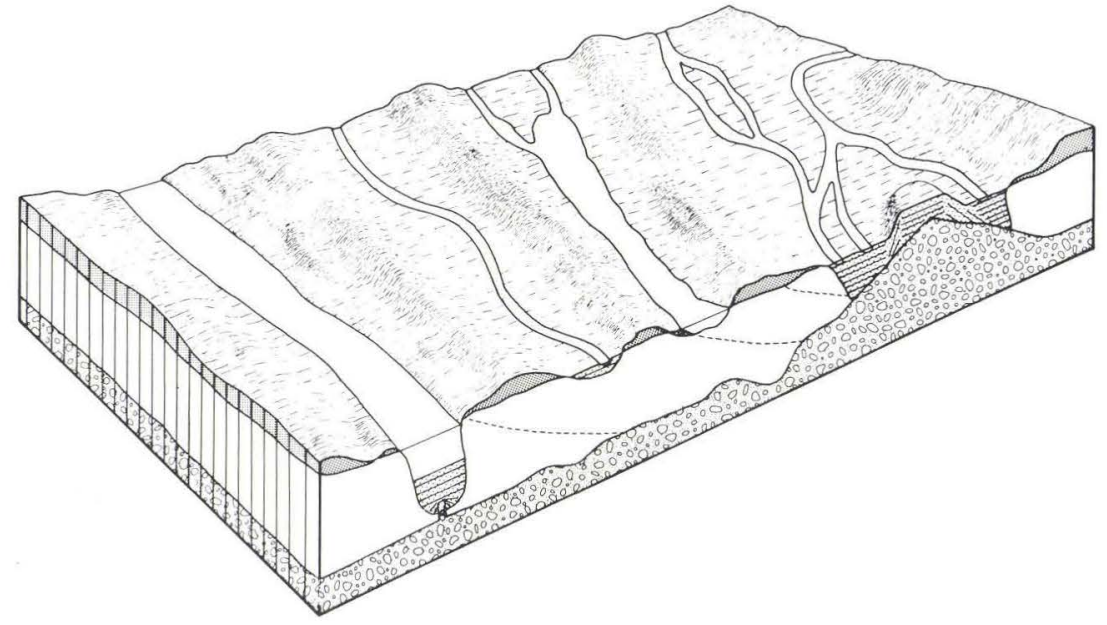

d.

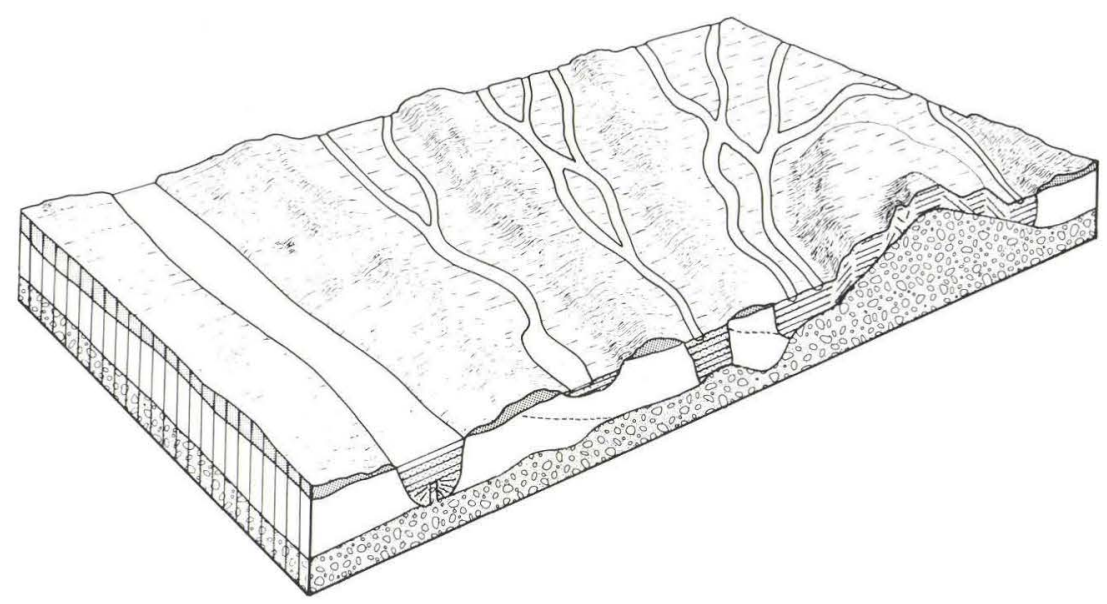

D.G.U. Marcussen May 1974 


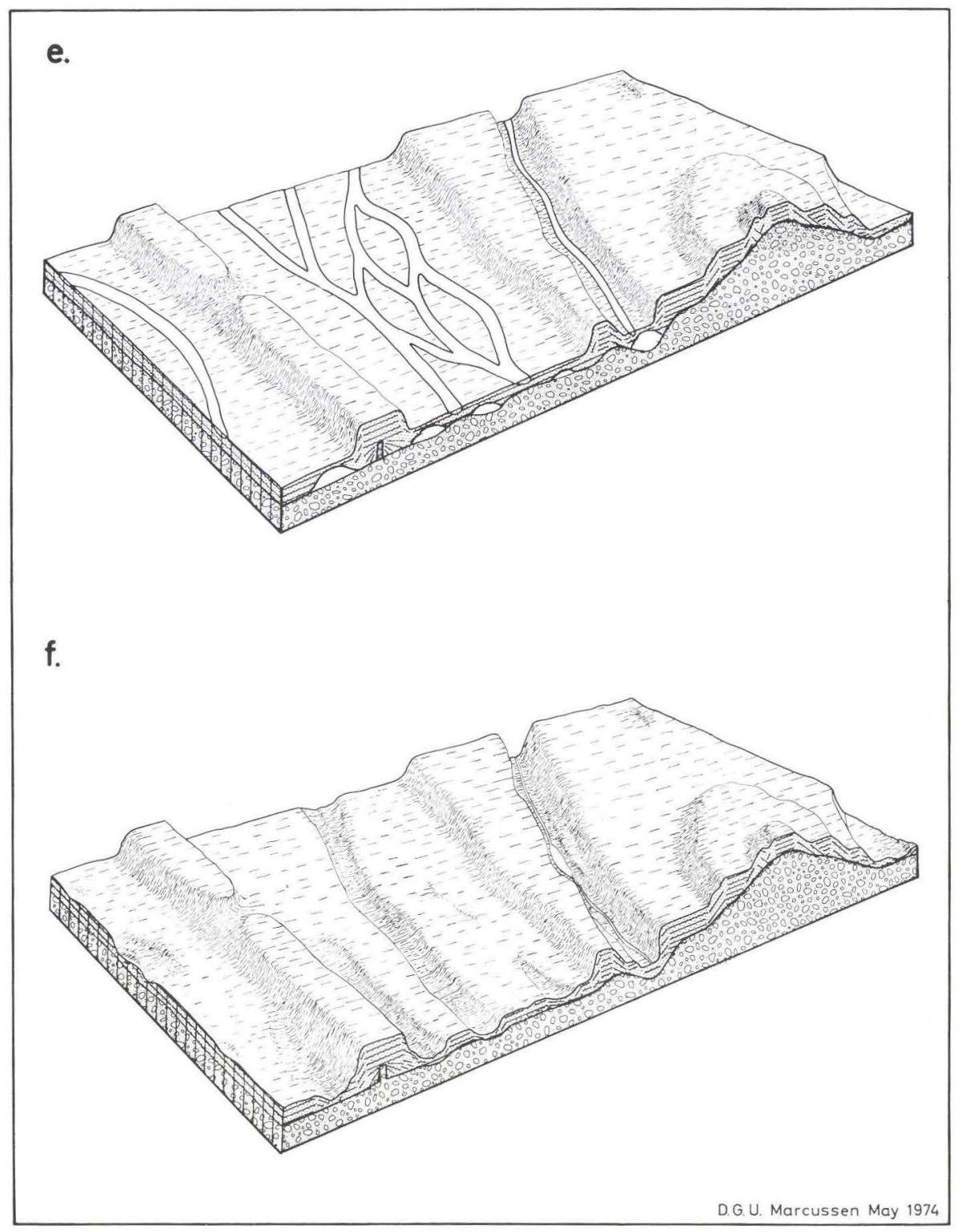

4 D.G.U. II. rk. nr. 110 
bedded sediments by the pressure of the surrounding dead-ice. Sigurd Hansen (1965) considers the squeezing of the till to have taken place into a crevasse in the bottom of the ice simultaneously with a lowering of the meltwater sediments down over the till-wall. Both explanations seem to give a possible explanation of the phenomenon, but the second one is most consistent with the fan-shaped setting of the surrounding sand. Furthermore, it seems to be supported by observations on glaciers in Iceland (Okko 1955). Fig. 12 comprises the second hypothesis.

The water released during the melting of the ice and water from precipitation will obviously also influence the deposits by erosion, and in many places traces of this can be observed. However, since these processes continued in the Flandrian, although probably to a minor extent, it can be difficult to decide when a certain feature has been formed, and no attempt has been made here.

The last processes which reasonably can be connected with the deglaciation phase are the sedimentation of sorted fine sediments into the depressions in the landscape. These processes occurred before dense vegetation covered the landscape and probably consisted of a washing out of the fine particles from the sediments in the surrounding hills (S. Hansen 1940). The sediments are usually well-sorted and most frequently consist of fine sand and silt. On geological maps they are marked as Late Glacial freshwater deposits: an unfortunate classification which should be replaced by another, as for example depression-deposits.

Because of the insulating properties of the sediments buried blocks of ice may be preserved for a long time. In the Danish area there is good evidence for the existence of ice in the ground until the Allerød chronozone (Hartz 1912, Degerbøl and Krog 1959) and maybe even to the beginning of the Flandrian (A. Andersen 1954). 


\section{Glaciological and climatological impli- cations for the last glaciation in Denmark}

In fig. 13 the altitudes of the observed down-wasting plains in Sjælland and the islands Lolland and Falster (about 9,000 $\mathrm{km}^{2}$ ), and in Fyn (about $3,000 \mathrm{~km}^{2}$ ) have been collected. To appraise the significance of the altitude of the plains it must be remembered that the topographical maps forming the basis for the investigation have contour intervals of 2.5 metres, and furthermore, that natural variations from dead level occur. The determination of the altitude of a plain has been made by interpolation between the highest areas in the plain. Since the variation in altitude is usually small in relation to the horizontal extension of the plain, this interpolation is considered to give a reasonable approximation. The postglacial shoreline displacement in this region has not been of a size which is considered large enough to have influenced the relationships between the plains.

On the right-hand side of fig. 13 an attempt has been made to correlate the plains in two regions. Considering the possibilities for variation in the processes supposed responsible, and the roughness in the determination of the altitude of the plains, the differences between the two regions are insignificant. In the light of the generally accepted hypothesis this conformity is amazing since the two regions are considered to have had quite a different development in the late part of the Weichselian glaciation. The demonstrated widespread occurrence of down-wasting plains indicates a continuity and approximate coincidence of the wasting processes over the entire area discussed. This provides a continuous ice cover over considerable parts of the Danish area. The observations are thus incompatible with the current opinions which imply a complicated sequence of glaciers in the area at the end of the Weichselian glaciation. But the hypothesis of an ice sheet is in agreement with the general pattern of predominant morphological features striking NW-SE, which can be observed all over the country (mentioned in a preliminary paper, Marcussen 1974).

In analogy with existing cold glaciers and ice sheets the Weichselian ice sheet must have contained only immaterial amounts of debris, except in the lower parts. Here the material from the substratum was assimilated in the regelation zone and transported by the internal flow. The decreasing slope of the surface of the ice sheet towards the south and southwest slowed 


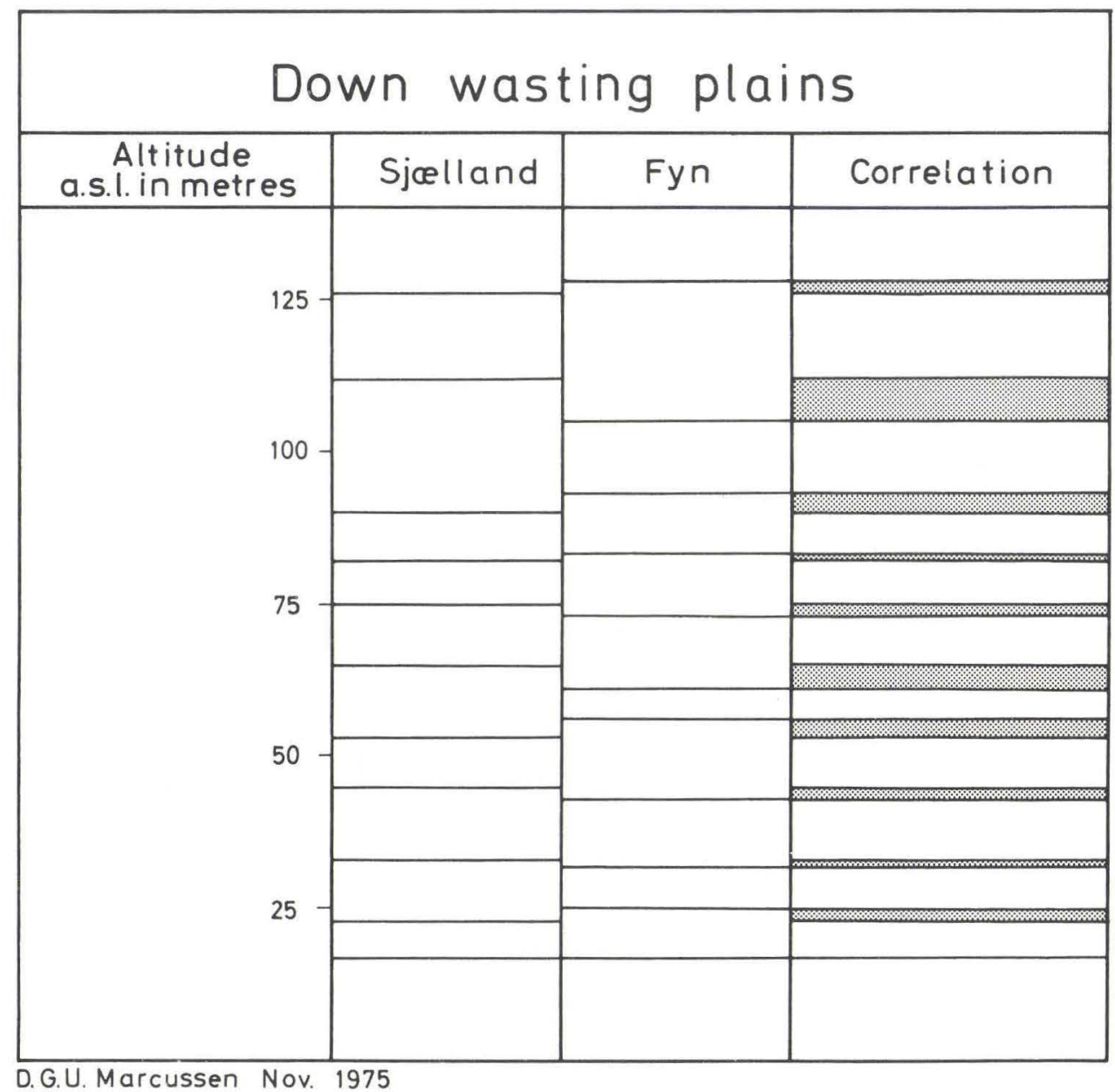

Fig. 13. Down-wasting plains on Sjælland and Fyn, and an attempt to make a correlation. The general character of the plains may indicate climatic fluctuations.

down the motion and promoted compressive flow which caused an upward transport of the debris-rich ice from the lowest parts of the glacier ice. Indications of compressive flow have been demonstrated and discussed elsewhere (Marcussen 1975). But it seems nevertheless reasonable to imagine that the surface of the ice sheet appeared white and clean during the main part of the glaciation including the essential part of the deglaciation. But as the wasting reached the lower parts of the ice sheet, more and more material was released on the surface. For these reasons detectable mor- 


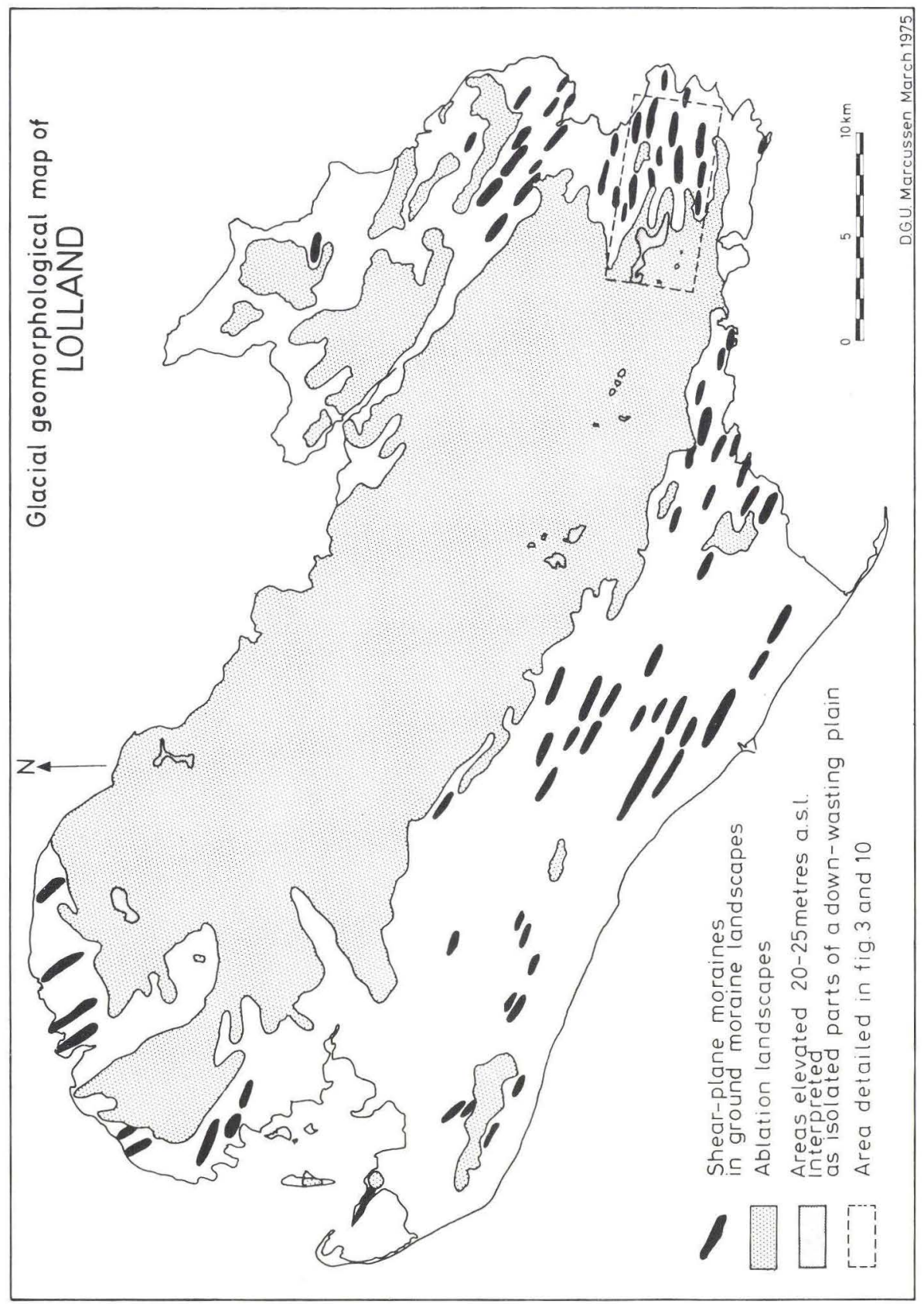

Fig. 14. Map indicating the extent of the ablation deposits in an area where ground moraine is also present. The map is drawn according to the concepts discussed in connection with fig. 10 . 
phological features can only be expected to represent the latest phases in the deglaciation.

The step-like arrangement of the down-wasting plains can naturally be interpreted as the result of changes in the wasting rate of the ice. The downwasting plains may then represent periods with a decrease or a stagnation in the ablation, during which a stabilization of the landscape took place. Basins were filled up to the maximum limit for the deposition, which was determined by thresholds reflecting the down-wasting level. Conversely, the vertical distances between the plains should represent unstable periods with increased ablation. Since ablation depends mainly on climatic conditions, the changes in the ablation rate may reflect cyclic changes in the climate. Accepting this idea, each plain can be interpreted as representing a climatic deterioration and the succeeding period of a relatively cold and presumably dry climate. The slopes should indicate periods of amelioration, with increased ablation as the result of an increased temperature and humidity in the summer and a prolonged ablation season (Wallén 1949). Cyclic changes in the climate of this character have been described from the Late Weichselian substage as well as from the Flandrian (Dansgaard et al. 1969, Emiliani 1974, Aaby 1975, 1976). To imagine a continuation of these climatic fluctuations backward seems reasonable and it gives a sensible explanation for the described phenomena.

The chronostratigraphical position of the recorded wasting sequence is in the latest part of the Middle Weichselian substage. The main part of the wasting had probably stopped at the end of this substage, so only isolated blocks of ice existed in the succeeding Late Weichselian substage. 


\section{Conclusion}

In the late Middle Weichselian, Denmark was covered with a continuous ice sheet of the subpolar type. The low relief and the increasing distance from the accumulation area provoked compressive flow in the ice sheet and this together with the unconsolidated basement resulted in assimilation of material from the substratum. The almost horizontal surface of the ice sheet made it sensible to climatic changes and the deglaciation may have occurred approximately simultaneously over wide areas. During the wasting clastic material was released on the surface of the ice sheet. The material appeared discontinuously and as it functioned as a protection against ablation the ice surface became uneven. Structures in the ice sheet related to the flow pattern were reflected at the surface. In question are structures which are parallel to, perpendicular to, or aligned at an angle of 45 degree to the direction of movement. These structures controlled the topography of the surface of the wasting ice to a high degree and thus controlled the deposition of the released material. In the present landscape these deposits appear as elongated hills and kames consisting of ablation deposits (meltwater sediments and flow till) situated in a pattern as outlined above. Deposits of this type have been termed controlled disintegration features by Gravenor and Kupsch (1959).

On the wasting ice sheet hollows were also formed which were apparently without relation to the above-mentioned structures. They had a subcircular form. Obviously the sedimentation tended to fill them up and they should then result in kame-like forms with a flat top, but the altitude of the tops of these deposits was not fixed until the sediments rested on the substraum of the ice. The flat tops constituted a plain. Through a widening of the basins, a general lowering of the ice surface, and continued sedimentation, plains were formed at still lower altitudes. In the present landscape these downwasting plains appear in a step-like manner with the oldest uppermost. The melting of the last parts of ice formed kettles or, if they had an elongated form, down-wasting valleys. The valleys may have existed prior to the deglaciation, but during this phase some important features were added.

The down-wasting plains apparently occur throughout the entire country and since it seems to be possible to correlate the altitude of the plains over 
large areas this may indicate that a general factor controlled the formation. This factor could be cyclic climatic changes and the down-wasting plains would then reflect the deteriorations and succeeding cold phases. 


\section{Acknowledgements}

The work has a background in many years of practical work in mapping the Quaternary deposits and I want here to express my sincere thanks to dr. phil. Helge Gry and to the late dr. phil. Hilmar $\varnothing d u m$ and dr. phil. Sigurd Hansen, who trained and introduced me to the traditional concepts, but at the same time inspired to rethinking. To dr. phil. Helge Gry, the former head of the department for Quaternary geology, I also wish to offer my warm thanks for encouragement and favourable working conditions. I am much indebted to the present head of the department dr. phil. Henning Sфrensen for reading the whole manuscript and making many helpful suggestions. I should like to thank cand. scient. Knud Binzer for the untold number of open-minded discussions during which many of the aspects were developed. To cand. scient.s Peter Konradi and Nils Bull I offer my warmest thanks for fruitful discussions.

The photos were made by Ove Neergaard Rasmussen, Inge Martin-Legéne produced the drawings and Janna Hansen typed the manuscript. Cand. scient. Mike Robson corrected my English manuscript. To these I give my best thanks for their help.

The English manuscript was completed in November 1976. 


\section{Dansk sammendrag}

\section{Deglaciations landskaber dannet under smeltningen af isskjoldet i sen mellem weichsel i Danmark}

De glaciale weichsel aflejringers stratigrafi er blevet diskuteret indgående i næsten hundrede år. Interessen har i særlig grad været rettet mod de fænomener, der har med den levende is at gøre. Specielt har vejene ad hvilke isen bevægede sig mod det danske område, og navnlig de baner isen fulgte inden for området, været diskuteret, og mange hypoteser er fremsat.

En glaciation kan imidlertid deles $\mathrm{i}$ ihvert fald to forskellige proceskredse og faser: Den euglaciale og den deglaciale. I den første er det i hovedsagen de fysiske forhold $\mathrm{i}$ isen (navnlig temperaturen), der betinger aflejringernes omfang og karakter. Under deglaciationen vil ismassen omdannes til vand (og små mængder til damp), og dette vil under indflydelse af de tilstedeværende smeltende ismasser præge aflejringerne. På grund af vandets evne til at erodere, transportere og aflejre kan det forventes, eller det er antagelig ligefrem en fysisk nødvendighed, at der afsættes ablations aflejringer.

Afhandlingen søger at demonstrere, at nogle landskabselementer kan tolkes som opstået under bortsmeltningen (deglaciationen) af weichselisen. Der lægges vægt på at sammenligne med observationen fra recente gletschere og isskjolde.

\section{Opfattelser $i$ den tidligere litteratur af weichsel isskjoldets glaciologiske forhold}

I den danske litteratur fremstilles weichsel glaciationens sedimenter og landskabsformer på en måde, der indebærer, at man får den opfattelse at ismasserne, der dækkede Danmark, var af den tempererede type. Fra akkumulationsområdet i Sydskandinaviens bjergegne bredte isen sig over lavlandene mod sydvest, syd og sydøst. Til Danmark anses isen at være kommet ad to veje med hver sin morfologiske gletscher type. Fra nord og nord$\varnothing$ st bredte et isskjold sig ned over den nordlige del af landet. Den anden indfaldsvej var fra sydøst, idet det antages at en stor gletscher skød ud fra isskjoldet i Mellemsverige og fulgte Østersøen mere eller mindre rundt om Sveriges sydkyst og ind over Danmark. Her bredte den sig ud som en piedmontgletscher. Den antages at have haft en stærkt lobat front. I slut- 
fasen skulle tungeformede gletschere af samme type som i bjergegne have skudt sig frem mod nord gennem Belterne.

I overensstemmelse med det aktualistiske princip søgte Ussing (1899, 1904) oplysninger om egnede gletschere eller isskjolde såvel blandt Europas gletschere som blandt arktiske ismasser i Island og Alaska. Disse sidste er i modsætning til de europæiske gletschere ofte stærkt materialefyldte, og Ussing mente, at de kunne give værdifulde informationer. Men på grund af et for lille erfaringsmateriale afgjorde Ussing ikke spørgsmålet, hvilken type der er bedst egnet til sammenligning.

V. Milthers (1900) tolkede de store bakkesystemer i Vestsjælland som randmoræner efter tre smalle gletschertunger. Milthers refererede ikke til nogen recent gletschertype, men det fremgår indirekte, at dalgletschere i Alperne har været brugt som model. Siden da har weichsel-isen i Danmark været tillagt træk, der er karakteristiske for tempererede ismasser af dalgletschertypen. Det blev imidlertid tidligt klart, at en række observationer er vanskelige at få til at passe med denne gletschermodel, og de tilskrives da de specielle forhold, man antager har eksisteret i det danske område (Harder 1908).

En tempereret gletscher er karakteriseret ved, at hele ismassen er på tryksmeltepunktet, og at ismassen derfor er permeabel for smeltevand. Isen glider over underlaget på en vandfilm og optager kun lidt af underlagets materiale i sin sål. Gletschere af denne type vil derfor kun aflejre bundtill (og bund-udsmeltnings-till). Den afsætning af klastisk materiale i s $\varnothing$ bassiner på toppen af isen, som antages at have dannet kames (kaldet plateaubakker når de består af ler) efter isens bortsmeltning er således i konflikt med den iøvrigt accepterede model. Et lignende forhold synes også at gøre sig gældende for dødishuller.

Den model for deglaciationen, der kan deduceres ud fra litteraturen, indebærer en frontal smeltning med stadige rejuveneringer af gletscherne, hvorved successive endemoræner blev opbygget. Deglaciationen skulle derfor være karakteriseret af serier af endemoræner med tilhørende sandurflader (hedesletter). Til trods for at et meget stort antal endemoræner er beskrevet i Østdanmark, er der kun påvist få og ubetydelige sandurflader.

Der synes således at være en række forhold, der vanskeligt lader sig forene, og det må derfor være rimeligt med en nyvurdering af de grundlæggende hypoteser. 
Generelle betragtninger vedrфrende glaciologiske, klimatologiske og sedimentologiske forhold

Skandinaviens bjergegne har været akkumulationsområde for isskjoldet i weichsel. Størrelsen af isskjoldet synes at have varieret i løbet af denne periode. Til det nordlige Jylland er isen dog først nået i den seneste del af mellem weichsel (Konradi og Knudsen 1974). Det må anses for rimeligt at antage, at isen også først er nået den фvrige del af landet på samme tid eller senere. Der er intet der tyder på, at landskabet forud for glaciationen havde væsentlig anderledes reliefforhold end de, der findes idag, og isen må derfor siges at have bredt sig ud over et fladt område (når man sammenligner med en formodet istykkelse og akkumulationsområdets relief). Tilsvarende forhold ved recente isskjolde betinger et simpelt flydem $\varnothing$ nster i isen og en ubrudt rand. Dog kan varierende mængde af klastisk materiale $\mathrm{i}$ isen tænkes at have givet anledning til uens bevægelseshastighed $\mathrm{i}$ isen og derfor at have forårsaget relative isstrømme inden for ismassen. Ved deduction må det derfor sluttes, at det skandinaviske isskjolds rand mod syd og sydvest i hovedsagen udgjorde en nogenlunde sammenhængende linie, og at flydem $\varnothing$ nstret var simpelt fra akkumulationsområdet mod sydvest ud mod isens randområder. En del observationer indicerer da også et sådant mønster.

De klimatiske forhold $\mathrm{i}$ den sene del af mellem weichsel i det danske område må bedømmes udfra observationer gjort uden for det nedisede område. Disse viser alle, at klimaet her har været arktisk. Isen kan derfor næppe have været tempereret, men må have været af den subpolare eller eventuelt af den polare type. I disse kolde gletschere er temperaturen under tryksmeltepunktet, og de er derfor impermeable for smeltevand. Gletscherne har en begrænset effekt på underlaget, idet de normalt vil være frosset fast. Dog kan der i de subpolare gletschere optræde vand som følge af tryksmeltning. Herved kan materiale fra underlaget optages $\mathrm{i}$ isen, hvor det derefter føres med i den indre flydning af ismassen. Det klastiske materiale kan føres højt op i isen og vil blive frigjort på isens overflade når isen smelter.

Smeltevandet vil primært danne strømme på isoverfladen fordi isen er impermeabel. Når det glaciale, klastiske materiale begynder at blive frigjort, opstår et ejendommeligt landskab, der er blevet betegnet termokarst. Efterladenskaberne af en total bortsmeltning kan forventes at bestå af lagdelte, sedimenter, der indgår i landskabsformer med en tilnærmelsesvis horisontal, flad overflade af samme type som en hedeslette. Men eftersom aflejringen sker i nær kontakt med den smeltede is, kan såvel lejringsforholdene som morfologien forventes at vise forstyrrelser.

Da isskjoldets overflade i det danske område må antages at have været næsten horisontal, vil en klimaforbedring have bevirket $\emptyset$ get ablation over 
store områder samtidigt. Deglaciationen må derfor være foregået som arealnedsmeltning snarere end som frontal smeltning af isskjoldet.

\section{Morfologiske og sedimentologiske observationer}

De morfologiske studier er udført på målebordsblade (1:20.000) og de sedimentologiske observationer er foretaget på DGU's kortblade og borearkiv og ved feltunders $\varnothing$ gelser.

Unders $\varnothing$ gelsen omfatter flader, »tunnel dale og vaskebratlignende landskaber.

Fladerne forekommer i to typer. Ortho-fladen er en sammenhængende flade med en svagt bølget topografi, der ikke danner noget konsekvent mønster. Para-fladen er beskrevet som en disintegreret flade bestående af enkeltbakker, der har samme tophøjde, og som hyppigt har en flad top.

Fladerne forekommer på en trappelignende måde i landskabet, og er hyppigt begrænsede af skrænter, der har is-kontakt karakter. De højestbeliggende er arealmæssigt de mindste og har altid stejle begrænsninger, medens de lavereliggende og navnlig de lavestliggende har mere jævne overgange til den nedenfor liggende flade.

I fig. 2 er de lavere liggende flader indtegnet i områder omkring Næstved. Mogenstrup åsen, som af Andersen (1931) er beskrevet som en spaltefyldning, kan følges mod nordvest til en stor flade sydvest for Tystrup-Bavelse s $\varnothing$. Ryggen såvel som fladen består af smeltevandssedimenter og flydetill.

Fig. 3 viser en flade på 20-25 m o.h., der ligger ovenpå de aflange bakker i den højre side af figuren. I fladen findes grusgrave, der viser lagdelte sedimenter. De lave bakker i højre side af figuren består derimod af meget fast moræneler.

Fig. 4 viser et eksempel på en para-flade. Tophøjden på de mest fremtrædende bakker er $45 \mathrm{~m}$ o.h. med et par meters afvigelse. Tilstedeværelsen af grusgrave og et teglværk indikerer den sedimentologiske opbygning.

»Tunnel« dalene har normalt en velmarkeret skulder mod den omgivende flade (fig. 5 og 6) og skrænterne har en is-kontakt karakter. I dalene er der terrasser, der hyppigt har tilknytning til hængende sidedale (fig. 7). Ofte kan en eller flere af terrasserne følges ud af dalen, hvor de så fortsætter som flader (fig. 2 og 7). Dalene slutter ofte i en rund cirkuslignende form, uden at de bliver snævrere. Dalbunden er typisk meget ujævn, og den overfladiske naturlige drænering er hyppigt dårlig.

I fig. 8 er et vaskebrætlignende landskab afbildet. Nederst i figuren findes en para-flade, som de aflange bakker $\emptyset$ verst i figuren gradvis går over i. De aflange bakker er ligesom para-fladen (fig. 9) opbygget af smeltevandssedimenter og flydetill. 


\section{Diskussion}

Fra den euglaciale fase må fænomener som skuring, drumlins, randmoræner og aflejringer som bund-till og udsmeltnings-till henføres. Tektoniske forstyrrelser af såvel glaciale som ældre aflejringer kan også finde sted i denne fase.

Deglaciations-processerne vil naturligvis i høj grad være præget af smeltevandets aktivitet. Omfanget af resultaterne af isens bortsmeltning vil i meget høj grad hænge sammen med mængden af indefrosset materiale $\mathrm{i}$ isen. Tempererede gletschere, der kun indeholder lidt materiale og kun i bundhorisonten, vil i alt væsentligt udelukkende give anledning til dannelse af sandurflader under bortsmeltningen. Anderledes vil det være, hvis isen indeholder meget materiale. Man kan i sådanne tilfælde forvente helt specielle aflejringstyper, der vil have lighed med kames eller sandurflader med dødishuller. Tektoniske deformationer kan forventes i disse aflejringer dels som følge af kollaps, dels som følge af lokalt betingede bevægelser $\mathrm{i}$ ismasserne. I de aflejringer, som beskrives her, findes hyppigt forstyrrelser af lejringsforholdene. En analyse er ikke gennemf $\varnothing \mathrm{rt}$ i denne afhandling, da mange forhold endnu synes uafklarede, men forstyrrelserne er underkastet indgående studier af flere forfattere.

I den tidligere danske litteratur har der været en tendens til at betragte de fleste glaciale dannelser som opstået subglacialt. I nærværende artikel bliver det diskuteret, om væsentlige dele af fænomenerne ikke kan hidrøre fra deglaciationen af en debrisrig ismasse. Diskussionen er på grund af disse modsætninger delt $\mathrm{i}$ to afsnit. Først diskuteredes de tidligere hypoteser og senere diskuteres en ny hypotese.

De flader, som Ussing (1904) og V. Milthers (1948) har beskrevet som moræneflader, kan deles i tre typer. Den første type har et lavt relief med distinkte aflange bakker, bestående af en kompakt till, der andet steds er tolket som bund-till. Disse flader tolkes derfor som bundmoræne.

Den anden type af flader er her beskrevet som vaskebrætlignende landskaber. De aflange bakker har mere sammensatte overfladeformer end de før nævnte. Sedimentologisk er bakkerne opbygget af både till og smeltevandssedimenter. Bakkerne i fig. 8 har været tolket som drumlins, men tilknytningen til para-fladen nederst i figuren taler mod en sådan tolkning. Imod denne tolkning taler også det forhold, at bakkerne er en del af det generelle mønster af aflange bakker, der kan følges til weichsel-isens yderste grænse i Nordtyskland. Madsen (1902) tolkede bakkerne som dannet nær isranden under deglaciationen. Da bakkerne adskiller sig både med hensyn til størrelse og sedimentologi fra vaskebrætmoræner og de Geer moræner, der begge består af bund-till, er de her blevet tolket som Thule-Baffin moræner (Goldthwait 1951). 
Den tredie type af flader viser udover fladheden ikke specifikke morfologiske karakterer. Disse flader ligner således aflejringerne i de såkaldte isdæmmede søer, men de indeholder ofte spredte forekomster af till-materiale. Da denne till på alle undersøgte lokaliteter viser flyde-till karakter, er den ikke af så stor betydning, set fra et genetisk synspunkt, da den er afsat i samme miljø som smeltevandssedimenterne. Ussing og Milthers tolkede fladerne som dannet under isen. Dette er ikke i modstrid med unders $\varnothing$ gelser fra recente gletschere, men er vanskeligt at få til at passe med: 1. det trappeformede arrangement af fladerne; 2 . opdelingen af en flade i mindre bakker; 3. fladernes fortsættelse om terrasser i dalene; 4. fladernes sedimentologiske opbygning. Eftersom flader i et landskab ofte kan sættes i forbindelse med fluvial aktivitet, har Gripp (1954) tolket fladerne som resultater af erosionsprocesser under deglaciationen. Den sedimentære opbygning synes snarere at vise en genese ved accumulation, og Gry (1952) tolker da også en para-flade på denne måde. Denne antagelse danner grundlaget for den hypotese, der fremsættes her.

» Tunnel«dalene kan have en simpel relation til dale i den prækvartære overflade, men kan også være helt uafhængige af disse. Tilstedeværelsen af uforstyrrede, højtliggende eem aflejringer i siderne af nogle dale (f. eks. Løvskal) viser, at disse dale er udformet i weichsel, antagelig ved erosion. Synspunktet om en erosiv oprindelse er i den tidligere litteratur blevet overført til alle »tunnel«dale. Men i et glacialt aflejringsmiljø kan en lavning også være opstået ved at ismasser har hindret aflejring.

Ussing (1907) antog, at smeltevandet frit kunne bevæge sig gennem isen og derfor ville samle sig ved bunden. Her kom det under stort hydrostatisk tryk, og begyndte at strømme ud mod isranden, idet det eroderede »tunnel «dalene. Det synes imidlertid usandsynligt, at et åbent hydraulisk system i et permeabelt materiale skulle have mulighed for at skabe de nødvendige tryk og trykgradienter. Hvis derimod isen var impermeabel, som i kolde gletschere, ville denne proces være mulig. Ved tilførsel af varme fra jorden eller et lokalt $\emptyset$ get tryk, ville vand kunne eksistere under eller $\mathrm{i}$ isen, men ved ændrede trykforhold eller tæt ved isranden, ville det i normale tilfælde fryse igen. De danske »tunnel«dale kan primært være opstået under forhold som de sidst skitserede. Dannelsen kan desuden tænkes at have foregået ved normal floderosion foran isen (under fremrykningen), men i så fald er der tilf $\varnothing$ jet væsentlige og nye træk under deglaciationen. 


\section{En ny hypotese}

Hvis weichsel isen var af den subpolare type og indeholdt klastisk materiale, kan aflejringer ældre end deglaciationsfasen være mere eller mindre dækket af et tæppe af ablations-sedimenter. Under isens bortsmeltning blev sedimentationen styret dels af smeltevandet og dels af den omgivende og underliggende is. Aflejringer afsat i bassiner oven på isen kan ved den fortsatte smeltning blive forstyrrede, og således få ændret såvel deres lejringsforhold som deres morfologiske form. Smeltevandets aktivitet vil stræbe mod at danne horisontale flader, og de tidligere beskrevne flader i det danske landskab tolkes som sådanne supraglaciale sandurflader. Den forskellige udformning af fladerne tolkes som et udtryk for varierende mængde af ma-teriale $\mathrm{i}$ isen fra en egn til en anden. Hvis isen var meget rig på klastisk materiale, vil strukturer $\mathrm{i}$ isen kun i ringe grad få indflydelse på aflejringernes morfologi, og de store flader som er vist $i$ fig. 2 vil udvikle sig. Med aftagende mængde materiale $\mathrm{i}$ isen vil det mønster, der stammer fra isens flydning, i højere og højere grad præge aflejringernes morfologi og deres udbredelse i landskabet. Aflange former, der antages at ligge vinkelret på isens bevægelsesretning, vil blive fremherskende (fig. 8). Sådanne former er blevet kontrollerede (Gravenor og Kupsch 1959).

Som følge af forskelle i ablationsdækkets tykkelse på isoverfladen foregik smeltningen af isen lokalt med varierende hastighed. På den måde kunne legemer af is blive liggende, selvom isen i omgivelserne var smeltet bort. Năr disse »dødis«blokke smeltede, dannedes lavninger i landskabet, der alt efter størrelse og form kaldes dødishuller eller dale.

\section{Arealsmeltning af et kontinentalt, koldt isskjold - en model}

På grund af den generelle klimaforbedring i den sene del af mellemste weichsel blev balancen mellem tilførsel og ablation i store dele af isskjoldet efterhånden negativ. Isen blev derfor først stagnerende og senere hen til dynamisk $d \varnothing d$ is. En medvirkende og forstærkende årsag til denne udvikling var isskjoldets næsten horisontale overflade.

Ved smeltningen af isen blev det indefrosne klastiske materiale frigjort på overfladen. Da materialet må formodes ikke at have været jævnt fordelt i isen, blev isoverfladen dækket af et uens tykt lag af sedimenter. Dette forărsagede, at smeltehastigheden ikke var den samme overalt, og overfladen blev derfor ujævn.

Udviklingen af dette komplicerede miljø er søgt illustreret $\mathrm{i}$ en serie blokdiagrammer, fig. 12. For overskuelighedens skyld er mange forhold simplifiserede i denne model. Underlaget for isen vil ikke udgøre en flade, men der vil være bakker og dale. Da der er indikationer for, at i det mind- 
ste nogle nedsmeltningsdale ligger over dale i den præglaciale overflade, er dette forhold inddraget i modellen. Tilsvarende er der mulighed for, at de højeste punkter i afsmeltningslandskabet ligger over højtliggende områder i den præglaciale overflade, hvilket der også er taget hensyn til på tegningen.

Det frigjorte klastiske materiale blev af smeltevandet afsat i bassiner på isoverfladen. Disse kan dels afspejle strukturen i isen, og vil da normalt være en aflang form, dels kan de være cirkulære. I sin mest udprægede form vil de aflange strukturer give anledning til vaskebrætlignende landskaber. De cirkulære og uregelmæssige former begynder antagelig som huller i isen, hvori der sker en sedimentation. Hvis hullet når gennem isen, således at sedimenterne hviler på isens underlag, vil aflejringen være fikseret og den vandrette overflade vil kunne bevares. Ved den fortsatte ablation vil bassinet udvide sig, samtidig med at isoverfladen kommer til at ligge lavere og lavere. Sedimentationen vil komme til at foregå udenom de tidligere afsatte sedimenter på et stadigt lavere niveau. Ved dette procesforløb dannes trin-pyramiden af nedsmeltningsflader. Højden til hvilken sedimentationen kan foregå vil være bestemt af en tærskelhøjde (en sedimentationstærskel), der igen er bestemt af, hvor langt nedsmeltningen er kommet (ablationsniveauet). Ved smeltning af is, der ligger under dele af en nedsmeltningsflade, sker en indsynkning. Hvis depressionen har en tilstrækkelig st $\varnothing \mathrm{r}-$ relse, vil der i den kunne dannes terrasser og hængende dale. En sådan dal er betegnet en nedsmeltningsdal. Forløbet af disse processer er s $\emptyset \mathrm{gt}$ afbildet i fig. 12 a-f.

\section{Glaciologiske og klimatologiske konsekvenser for den sidste} glaciation af Danmark

I fig. 13 er højden af nedsmeltningsflader på Sjælland med Lolland og Falster og på Fyn sammenstillet. I figurens højre side er der forsøgt en korrelation. Når variationen i de formodede dannelsesprocesser, og nøjagtigheden hvormed fladernes højde bestemmes, tages i betragtning, må forskellene mellem de to områder siges at være ubetydelige. Denne sammenhæng mellem områderne tolkes som et udtryk for en samhørighed i nedsmeltningen, og derfor også som udtryk for, at et sammenhængende isdække lå over hele området. Denne antagelse er i strid med de almindeligt accepterede hypoteser, men er i overensstemmelse med det generelle mønster af morfologiske træk, der er observeret over store dele af landet (Marcussen 1974).

I lighed med nutidige subpolare gletschere indeholdt weichsel isskjoldet kun debris i de nederste dele. Den aftagende hældning af isoverfladen mod 
syd og sydvest bremsede isbevægelsen, og forårsagede kompressive flydning, hvorved der skete en opadgående transport af isens nedre dele. Indikationer for denne flydning er tidligere beskrevet (Marcussen 1975). Klastisk materiale kan på denne måde være blevet ført højt op over isens sål. Alligevel må det antages, at de $\varnothing$ verste dele af isen har været rene. Først da ablationen nåede et godt stykke ned i ismassen, dækkedes isen af debris. Af denne grund kan også kun den sidste del af deglaciationen antages at have efterladt genkendelige morfologiske former.

Det trappelignende arrangement af nedsmeltningsfladerne kan tænkes at være et resultat af ændringer i ablationsraten. Nedsmeltningsfladerne kan repræsentere perioder med formindsket smeltning, i hvilke en stabilisering af landskabet fandt sted. De vertikale afstande mellem fladerne kan svare til ustabile perioder med forøget ablation. Da ablationen i hovedsagen er afhængig af klimatiske forhold, kan svingninger i ablationsraten reflektere cycliske forandringer af klimaet. Under denne forudsætning kan fladerne repræsentere klimaforværringer og den efterfølgende kolde og muligvis tørre periode. De vertikale dele antages at indicere klimaforbedringer med højere temperaturer og større luftfugtighed. Cycliske svingninger af denne karakter er påvist i flandrian og sen-weichsel, og det er rimeligt at antage, at de også kan have fundet sted i mellem-weichsel. 


\section{References}

Aaby, B. 1975: Klimavariationer med samme periodicitet de sidste 7.500 år påvist ved undersøgelser af højmoser og marine transgressionsfaser. - Danm. Geol. Unders., Arbog 1974, pp. 91-104.

Aaby, B. 1976: Cyclic variations in climate during the last 5500 years revealed by studies of raised bogs. Nature, 263, pp. 281-284.

Aartolahti, T. 1974: Ring ridge humocky moraines in northern Finland. - Fennia $134,22 \mathrm{p}$.

Andersen, A. 1954: Two Standard pollen diagrams from south Jutland. - Danm. Geol. Unders. II. række, 80 , pp. 188-209.

Andersen, H. Lykke 1973: En begravet dal i præ-kvartæret ved Århus. - Dansk geol. Foren., Årsskrift for 1972, pp. 111-118.

Andersen, S. A. 1924: Kvartærgeologiske Iagttagelser i Egnen Syd for Sor $\varnothing$. - Meddr dansk geol. Foren. 6, 22, pp. 1-30.

Andersen, S. A. 1931: Om Aase og Terrasser indenfor Susaa's Vandomraade. - Danm. Geol. Unders. II række, 54, 167 p.

Andersen, S. A. 1964: Grusgravene i bakkerne ved Kalundborg. - Meddr dansk geol. Foren., 15, pp. 359-367.

Andersen, S. Th. 1965: Interglacialer og interstadialer i Danmarks Kvartær. - Meddr dansk geol. Foren., 15, p. 486-506.

Berthelsen, A. 1972: Flod-, fjord- og tunneldale. - Dansk geol. Foren., Arsskrift for 1971, pp. 101-104.

Berthelsen, A. 1974: Nogle forekomster af intrusivt moræeler i NØ-Sjælland. - Dansk geol. Foren., Arsskrift for 1973, pp. 118-131.

Bishop, B. C. 1957: Shear moraines in the Thule area, northwest Greenland. - U.S. Snow, Ice and Permafrost Research Establishment, Res. Rep. 17.

Boulton, G. S. 1967: The development of a complex supraglacial moraine at the margin of Sørbreen, Ny Friesland, Vestspitsbergen. - J. Glaciol., 6, pp. 717-735.

Boulton, G. S. 1968: Flow tills and related deposits on some Vestspitsbergen Glaciers. - J. Glaciol., 7, pp. 391-412.

Boulton, G. S. 1970: On the origin and transport of englacial debris in Svalbard glaciers. - J. Glaciol., 9, pp. 213-229.

Boulton, G. S. 1971: Till genesis and fabric in Svalbard, Spitsbergen. - In Goldthwait, R. P. (ed): Till, a symposium. pp. 41-72. Ohio State University Press, Columbus.

Boulton, G. S. 1972a: Modern arctic glaciers as depositional models for former ice sheets. - J. geol. Soc. Lond., 128, pp. 361-393.

Boulton, G. S. 1972b: The role of thermal regime in glacial sedimentation. - Inst. Br. Geogr., Special Publ. 4, 19 p.

Bull, N., Kallesøe, R. and Kærgaard, H. 1976: Rapport over hydrogeologisk kortlægning af et område ved Horsens. - Internal Rap. Danm. geol. Unders., 58 p. 
Bülow, K. v. 1928: Die Rolle der Toteisbildung beim letzten Eisrückzug in Norddeutschland. - Z. dt. geol. Ges., 79, pp. 273-283.

Clayton, L. 1964: Karst topography on stagnant glaciers. - J. Glaciol., 5, pp. 107-112.

Cook, H. J. 1946: Kame-complexes and perforation deposits. - Am J. Sci., 244, pp. 573-583.

Coope, G. R., Morgan, A. and Osborne, P. J. 1971: Fossil Coleoptera as indicators of climatic fluctuations during the Last Glaciation in Britain. - Palaeogeogr., Palaeoclimatol., Palaecol., 10, pp. 87-101.

Dansgaard, W., Johnsen, S. J., Møller, J. and Langway, Jr. C. C. 1969: One thousand centuries of climatic record from Camp Century on the Greenland Ice sheet. Science, N. Y., 166, pp. 377-381.

Degerb $\varnothing 1$, M. and Krog, H. 1959: The Reindeer (Rangifer taradus L.) in Denmark. Briol. Skr. 10, no. 4, 165 p.

Elson, J. A. 1953: Periodicity of deglaciation in North America since the late Wisconsin maximum. Part II. Late Wisconsin recession. - Geogr. Annaler, 35, pp. 95-104.

Elson, J. A. 1957: Origin of washboard moraines. - Bull. geol. Soc. Am., 68, p. 1721.

Embleton, C. and King, C. A. M. 1969: Glacial and periglacial geomorphology. Edward Arnold, London, 608 p.

Emiliani, C. 1974: Isotopic paleotemperatures and shell morphology of Globigerinoides rubra in the Mediterranean deep-sea core 189. - Micropaleontology, 20, 1, pp. 106-109.

Flint, R. F. 1928a: Eskers and crevasse Fillings. - Am. J. Sci., ser. 5, 15, pp. 410416.

Flint, R. F. 1928b: Pleistocene terraces of the Lower Connecticut Valley (abstract). Bull. Geol. Soc. Am., 39, pp. 216-217.

Flint, R. F. 1929: The stagnation and dissipation of the last ice sheet. - Geogrl. Rev., pp. 256-289.

Flint, R. F. 1933: Late-Pleistocene sequence in the Connecticut Valley. - Bull. geol. Soc. Am., 44, pp. 965-988.

Flint, R. F. 1942: Glacier thinning during deglaciation. - Am. J. Sci., 240, pp. 113136.

Fristrup, B. 1963: Indlandsisen. - Rhodos, København, 240 p.

Glen, J. W. 1954: The stability of ice-dammed lakes and other water-filled holes in glaciers, - J. Glaciol., 2, pp. 316-318.

Goldthwait, J. W. 1938: The uncovering of New Hampshire by the last ice sheet. Am. J. Sci., 36, pp. 345-372.

Goldthwait, R. P. 1951: Development of end moraines in east-central Baffin Island. J. Geol., 59, pp. 567-577.

Gravenor, C. P. 1955: The origin and significance of prairie mounds. - Am. J. Sci., 253, pp. 475-481.

Gravenor, C. P. and W. O. Kupsch 1959: Ice-disintegration features in Western Canada. - J. Geol. 67, pp. 48-64.

Gripp, K. 1929: Glaciologische und geologische Ergebnisse der Hamburgischen Spitzbergen-Expedition 1927. - Naturw. Ver. Hamburg, 22, pp. 145-249.

Gripp, K. 1949: Die Entstehung der Föhrden. - Schr. naturw. Ver. Schlesw.-Holst., 24, pp. 67-69.

Gripp, K. 1954: Die Entstehungen der Landschaft Ost-Schleswigs vom Dänischen Wohld bis Alsen. - Meyniana, 2, pp. 81-123. 
Gripp, K. 1964: Erdgeschichte von Schleswig-Holstein. - Karl. Wachholtz Verlag, Neumünster, $411 \mathrm{p}$.

Gripp, K. \& Todtmann, E. 1926: Die Endmoränen des Green Bay Gletschers auf Spitzbergen. - Mitt. dt. Geogr. Ges., 37, pp. 43-75.

Gry, H. in: Gry, H. og Milthers, K. 1952: Ekskursion til Kalundborg-egnen. - Meddr dansk geol. Foren., 12, pp. 322-323.

Haarsted, V. 1956: De kvartærgeologiske og geomorfologiske forhold på Møn. - Meddr dansk geol. Foren. 13, pp. 124-126.

Hammen, T. van der, Wijnstra, T. A. and Zagwijn, W. H. 1971: The floral record of the Late Cenozoic of Europe. - In: Turekian, K. K. (ed.) The Late Cenozoic Glacial Ages. pp. 391-424. Yale University.

Hammerüller, B. 1907: Laaland-Falster. Entwicklung des Bodenreliefs, Stromtäler und Küstenbildung. - Diss. Universität zu Leipzig.

Hansen, K. 1944: Investigations of the geography and natural history of the Præst $\varnothing$ Fjord, Zealand. - Folia Geogr. Danica III, 1, 46 p.

Hansen, K. 1971: Tunnel valleys in Denmark and Northern Germany. - Bull. geol. Soc. Denmark, 20, pp. 295-306.

Hansen, K. 1975: The Salten Valley. - Dansk geol. Foren., Arsskrift for 1974, pp. $5-23$.

Hansen, S. 1940: Varighed i danske og skaanske senglaciale Aflejringer. - Danm. geol. Unders., II række, 63, 478 p.

Hansen, S. 1942: En isskruet »Brolægning fra Egnen NØ for Odense. - Meddr dansk geol. Foren., 10, pp. 119-129.

Hansen, S. 1965: The Quaternary of Denmark. - In: Rankama, K. (ed.), The Geologic Systems. The Quaternary pp. 1-90, Interscience publishers, New York.

Harder, P. 1908: En фstjydsk Israndslinje og dens Indflydelse paa Vandløbene. Danm. geol. Unders., II række, 19, 259 p.

Hartz, N. 1909: Bidrag til Danmarks tertiære og diluviale Flora. - Danm. geol. Unders., II række, 20, $292 \mathrm{p}$.

Hartz, N. 1912: Aller $\varnothing$ d-Muld: Aller $\varnothing$ d-Gytjens Landfacies. - Meddr Dansk geol. Foren. 4, pp. 61-68.

Hartz, N. and Østrup, E. 1899: Danske Diatoméjord-Aflejringer og deres Diatoméer. - Danm. geol. Unders. II række, 9, 81 pp.

Hooke, R. LeB. 1970: Morphology of the ice-sheet margin near Thule, Greenland. J. Glaciol. 9, pp. 303-324.

Hoppe, G. 1948: The ice recession from the lower regions of Norrbotten as illustrated by the land formations. - Geographica 20, pp. 104-108.

Hoppe, G. 1952: Hummocky moraine regions with special reference to the interior of Norrbotten. - Geogr. Annaler, 34, pp. 1-72.

Hoppe, G. 1957: Problems of glacial morphology and the Ice Age. - Geogr. Annaler., 39, pp. 1-18.

Hoppe, G. 1959: Glacial morphology and inland ice recession in north Sweden. Geogr. Annaler, 41, pp. 193-212.

Jahns, R. H. and M. E. Willard 1942: Late Peistocene and Recent deposits in the Connecticut valley, Massachusetts. Part 1 and 2. - Am. J. Sci., 240, pp. 161-191, pp. 265-287.

Jensen, V. 1974: Den strukturelle opbygning af klinterne ved Lynæs. - Dansk geol. Foren., Arsskrift for 1973, p. 205.

Jessen, A. 1918: Vendsyssels Geologi. - Danm. geol. Unders. V række, 2, 260 p. 
Jessen, A. 1935: Kortbladet Haderslev. - Danm. geol. Unders. I række, 17, 95 p.

Jessen, A. 1936: Vendsyssels Geologi. - Danm. geol. Unders. V række, 2, 195 p.

Jessen, K. and Milthers, V. 1928: Stratigraphical and paleontological studies of interglacial fresh-water deposits in Jutland and northwest Germany. - Danm. geol. Unders. II række, 48, $380 \mathrm{p}$.

Kellogg, Th. B. 1976: Late Quaternary climatic changes: Evidence from deep-sea cores of Norwegian and Greenland seas. - Mem. Geol. Soc. Am. 145, pp. 77-110.

King, C. A. M. 1975: Some comments on the glacial geomorphology of the Viborg area of Jutland, Denmark. - Geogr. Tidsskr. 74, pp. 1-11.

Klajnert, Z. 1966: Geneza Wzgórz Domaniewickich i uwagi o sposobie zaniku lodwca Srodkowopolskiego. - Acta geogr. lodz., 23. 136 p. (Summary in English).

Konradi, P. and Knudsen, K. L. 1974: In: Bahnson, H., Petersen, K. Strand, Konradi, P. and Knudsen, K. L. Stratigraphy of Quaternary deposits in the Skærumhede II boring: lithology, molluscs and foraminifera. - Danm. geol. Unders., Årbog 1973, pp. 27-62.

Krüger, J. 1969: Landskabsformer i sydlige Sjælland. - Geogr. Tidsskr. 68, pp. 105212.

Lundqvist, G. 1954: Räfflor, ändmoräner och isrecessionslinjer. In: Atlas över Sverige. Atlasblad 21-22. Generalstabens litografiska anstalts förlag, Stockholm.

Lundqvist, J. 1974: Outlines of the Weichsel Glacial in Sweden. - Geol. För. Stockh. Förh. 96, pp. 327-339.

Mackay, J. R. 1960: Crevasse fillings and ablation slide moraines, Stopover Lake area, N. W. T. - Geogrl. Bull., 13-15, pp. 89-99.

Madsen, V. 1902: Kortbladet Nyborg. - Danm. geol. Unders. I række, 9, 182 p.

Madsen, V. 1903: Om den glaciale, isdæmmede S $\varnothing$ ved Stenstrup paa Fyn samt om Dannelsen af Teglværksleret i Stenstrup-egnen. - Danm. geol. Unders., II række, $14,86 \mathrm{p}$.

Marcussen, I. 1973: Studies on flow till in Denmark. - Boreas 2, pp. 213-231.

Marcussen, I. 1974: En ny opfattelse af den sidste glaciation i det sydøstlige Danmark. - Uppsalasymposiet 1974, pp. 13-16.

Marcussen, I. 1975: Distinguishing between lodgement till and flow till in Weichselian deposits. - Boereas 4, pp. 113-123.

Markus, E. 1930: Kameslandschaften Estlands. - Z. dt. geol. Ges. 82, pp. 53-59.

Mawdsley, J. B. 1936: Washboard moraines of the Opawica-Chibougamau District, Quebec. - Trans. R. Soc. Can. Ser. 3, sect. IV, 30, pp. 9-12.

McIntyre, A. and Ruddimann, W. F. 1972: Northwest Atlantic Post-Eemian Paleooceanography: A Predictive Analog of Future. - Quat. Res. (Wash., Univ., Quat. Res. Cent.) 2, pp. 350-354.

McKenzie, G. D. 1969: Observations on a colapsing kame terrace in Glacier Bay National Monument, southeastern Alaska. - J. Glaciol. 8, pp. 413-425.

Mertz, E. L. 1937: Geologiske Profiler gennem danske Sunde og Fjorde. - Danm. geol. Unders. II række, 60, 143 p.

Mertz, E. L. 1955: De danske jordarter som byggegrund. - Statens Byggeforskningsinstitut Anvisning 28. København.

Mertz, E. L. 1959: Bidrag til Danmarks ingeniфrgeologi. - Bull. Geotek. Inst. 5, 28.

Milthers, K. 1942: Ledeblokke og Landskabsformer i Danmark. - Danm. geol. Unders. II række, 69, $137 \mathrm{p}$.

Milthers, V. 1900: In: Rørdam, K. og Milthers, V. Kortbladene Sejr $\varnothing$, Nykøbing, Kalundborg og Holbæk. - Danm. geol. Unders. I række, 8, 143 p. 
Milthers, V. 1909: Scandinavian indicator-boulders in the Quaternary deposits. Danm. geol. Unders. II række, 23, 153 p.

Milthers, V. 1928: Glacialgeologiske Retningslinjer i Odense Egnen. - Danm. geol. Unders. IV række, 2, 4, $24 \mathrm{p}$.

Milthers, V. 1932: Israndens Tilbagerykning fra Østjylland til Sjælland-Fyn, belyst ved Ledeblokke. - Danm. geol. Unders. IV række 2, 9, 70 p.

Milthers, V. 1940: Beskrivelse til Kortbladet Vissenbjærg. - Danm. geol. Unders. I række, 19, $143 \mathrm{p}$.

Milthers, V. 1948: Det danske Istidslandskabs Terrænformer og deres Opstaaen. Danm. geol. Unders. III række, 28, 233 p.

Niewiarowski, W. 1957: Morphological evidence of deglaciation by melting away of continental glacier over large areas as illustrated by landsforms in the region of Kowalewo, Golub and Wąbrzeźno. - Bull. Acad. pol. Sci., Sér. Sci. chim. geol. geogr., Cl. III, 5, 10.

Niewiarowski, W. 1959: Formy polodowcowe i typy deglacjacji na Wysoczyźnie Chetmińskiej. - Studia Soc. Sci. torum, 4, 1.

Niewiarowski, W. 1963: Some problems concerning deglaciation by stagnation and wastage of large portions of the ice-sheet within the area of the last glaciation in Poland. - Rep. 6th Conf. int. Ass. quatern. Res. (Warsaw, 1961) Lodz (1963), 3, 245-56.

Niewiarowski, W. 1965: Kemy i formy Pokrewne W Danii Oraz Rozmieszczenie Obszarów Kemowych Na Tereniw Peribalticum W Obrębie Ostaniwgo Zladowacenia. - Uniwersytet M. Kopernika W Turunin Nauki Matem. - Przyrodnicze, 11.

Nordmann, V. 1922: Nye Iagttagelser over den glaciale, isdæmmede S $\varnothing$ ved Stenstrup paa Fyn. - Danm. geol. Unders. IV række, 1, 17, 25 p.

Nordmann, V. 1958: Kortbladet Fredericia. A: Kvartære aflejringer. - Danm. geol. Unders. I række, 22-A, 125 p.

Okko, V. 1955: Glacial drift in Iceland its origin and morphology. - Bull. Comm. geol. Finl., 170, 133 p.

Parizek, R. R. 1969: Glacial ice-contact rings and ridges. - Spec. Pap. Geol. Soc. Am., 123, 49-102.

Price, R. J. 1969: Moraines, sandar, kames and eskers near Breidamerjökull, Iceland. - Trans. Inst. Br. Geogr., 46, pp. 17-43.

Rasmussen, L. Aabo 1975: Kineto-stratigraphic glacial drift units on Hindsholm, Denmark. - Boreas, 4, pp. 209-217.

Reid, J. R. \& Clayton, L. 1963: Observations of rapid water-level fluctuations in ice sink-hole lakes, Martin River Glacier, Alaska. - J. Glaciol., 4, pp. 650-652.

Rice, H. M. A. 1936: Glacial phenomena near Cranbrook, British Columbia. - J. Geol., 44, pp. $68-73$.

Rice, H. M. A. 1937: Cranbrook Map-area, British Columbia. - Mem. geol. Surv. Brch. Canada, 207, 67 p.

Rich, J. L. 1943: Buried stagnant ice as a normal product of a progressively retreating glacier in a hilly region. - Am. Jour. Sci. 241, pp. 95-100.

Richter, K. 1937: Die Eiszeit in Norddeutschland. - Verlag von Gebrüder Borntraeger. Berlin. 179 p.

Russel, I. C. 1891: An expedition to Mount St. Elias, Alaska. - Natn. geogr. Mag., 3, pp. 53-191.

Russell, I. C. 1897: Glaciers of North America. - Ginn and Company, Publishers. Boston. 210 p. 
Sagar, R. B. 1966: Glaciological and climatological studies of the Barnes ice cap, 1962-64. - Geogr. Bull. 8, pp. 3-47.

Schou, A. 1962: The construction and drawing of block diagrams. - Nelson and Sons Ltd, London. 33 p.

Schrøder, N. 1973: Meltwater rivers in northern Jylland and Kattegat. - XI Nordiska Geologiska Vintermötet Oulu 1974. pp. 31-36.

Sharp, R. P. 1947: The Wolf Creek glaciers, St. Elias Range, Yukon Territory. Geogrl. Rev. 37, pp. 26-52.

Sharp, R. P. 1949: Studies on superglacial debris on valley glaciers. - Am. J. Sci., 247, pp. 289-315.

Sjørring, S. 1974: Klinterne ved Hundested. - Dansk geol. Foren., Årsskrift for 1973. pp. $108-117$.

Smed, P. 1962: Studier over den fynske фgruppes glaciale landskabsformer. - Meddr dansk geol. Foren. 15, pp. 1-74.

Sorgenfrei, Th. and Berthelsen, O. 1954: Geologi og vandboring. - Danm. geol. Unders., III række, 31, 106 p.

Souchez, R. A. 1966: The origin of morainic deposits and the characteristics of glacial erosion in western Sør Rondane, Antarctica. - J. Glaciol. 6, pp. 249-254.

Stenestad, E. 1976: Københavns geologi - især baseret på citybaneunders $\varnothing$ gelserne. Danm. geol. Unders. III række, 45. 149 p.

Sugden, D. E. and John, B. S. 1976: Glaciers and landscape. - Edwald Arnold Ltd, London. 376 p.

Tarr, R. S. 1909: Yakutat Bay region, Alaska. - U. S. Geol. Surv., Prof. Pap. 64, $183 \mathrm{p}$.

Torell, O. 1972: Undersökningar öfver istiden. - K. svenska Vetensk. Akad. Förh., 10, pp. 25-64.

Ussing, N. V. 1899: Danmarks Geologi. - Danm. geol. Unders. III raekke, 2, 264 p.

Ussing, N. V. 1900: In: Noe Nygaard, A. 1976: Et fors $\emptyset$ g, som slog fejl. - Dansk geol. Foren., Årsskr. for 1975, pp. 1-4.

Ussing, N. V. 1903: Om Jyllands Hedesletter og Teorierne for deres Dannelse. - K. dansk Vidensk. Selsk. Skr., 2, pp. 99-164.

Ussing, N. V. 1904: Danmarks geologi. - Danm. geol. Unders. III raekke, 2. ed. $359 \mathrm{p}$.

Ussing, N. V. 1907: Om Floddale og Randmoræner i Jylland. - K. dansk Vidensk. Selsk. Skr., 4, pp. 161-213.

Wallén, C. C. 1949: Glacial-Meteorological investigations on the Kårsa Glacier in Swedish Lappland 1942-1948. - Geogr. Annaler, pp. 451-672.

Ward, W. H. 1951: The physics of deglaciation in central Baffin Island. - Ass. Int. d'Hydrol. Scient., Assemblée Générale de Bruxelles. pp. 237-245.

Weertman, J. 1961: Mechanism for the formation of inner moraines found near the edge of cold ice caps and ice sheets. - J. Glaciol. 3, pp. 965-978.

Wolsted, P. 1952: Die Entstehung der Seen in den ehemals vergletscherten Gebieten. - Eiszeitalter Gegenw. 2, pp. 146-153.

Wolff, W. 1928: Einige glazialgeologische Probleme aus dem norddeutschen Tiefland. - Z. dt. geol. Ges., 79, pp. 342-360.

Wright, Jr. H. E. 1973: Tunnel Valleys, Glacial Surges, and Subglacial Hydrology of the Superior Lobe, Minnesota. - Geol. Soc. Am., Mem. 136, pp. 251-276.

Ødum, H. 1969: Kvartæret omkring Hobro. - Danm. geol. Unders. IV række 4, 10, $23 \mathrm{p}$. 
Aפ) 